\title{
REESTRUTURAÇÃO \\ PRODUTIVA E NEGOCIAÇÃO COLETIVA NOS ANOS 90
}

\author{
Angela Maria Carneiro Araújo \\ Daniela Maria Cartoni \\ Carolina Raquel D. Mello Justo
}

\section{Introdução}

O processo de modernização e reestruturação na indústria e no setor bancário brasileiros teve início no final dos anos 70 , intensificou-se em meados dos 80 e acelerou-se bastante nos anos 90, alterando profundamente as características do trabalho. Assim, ao longo das duas últimas décadas, assistimos a um processo de mudanças sucessivas no interior das empresas e bancos que se referem tanto à adoção de inovações tecnológicas e organizacionais, em graus variados de profundidade e extensão, quanto à percepção e reação dos atores envolvidos.

A reestruturação da indústria e do sistema bancário brasileiros, nos anos 80 , ocorreu em um contexto de crise econômica, marcado pela recessão e pelo crescimento do desemprego, e ao mesmo tempo de redemocratização política e fortalecimento do movimento sindical no país, na contramão das tendências de enfraquecimento e crise do sindicalismo internacional. Ao longo do processo de redemocratização política, sob a pressão da mobilização de base e da intensificação da luta grevista, o funcionamento e o papel dos sindicatos oficiais foram alterados, com a progressiva liberalização do controle do Estado sobre a sua atividade e a substituição do "peleguismo" por lideranças mais atuantes. Neste contexto, as greves e a prática da negociação coletiva foram os principais instrumentos de reconstrução do movimento sindical, bem como de redefinição das relações de trabalho no país. Através delas os sindicatos conquistaram seu reconhecimento como interlocutores legítimos junto ao empresariado e ao Estado, além de espaço político na sociedade.

Nos anos 90, a adoção de políticas de corte neoliberal, ${ }^{1}$ que promoveram a abertura comercial e a internacionalização da economia, aprofundou o processo de introdução de inovações tecnológicas e de novos métodos de gestão da força de trabalho. Acrescentam-se a isso, mais recentemente, as tentativas de desregulamentação do mercado de trabalho, principalmente mediante a flexibilização dos contratos. Este conjunto de transformações teve como conseqüências sociais importantes a precarização e informalização do trabalho e o crescimento do desemprego, que ampliaram a fragmentação dos coletivos de trabalhadores e tiveram forte impacto sobre as relações de trabalho e sobre as organizações sindicais.

Estas transformações e as grandes alterações nas condições do mercado de trabalho que elas 
provocaram mudaram a correlação de forças de modo desfavorável aos trabalhadores. Neste contexto, grande parte dos sindicatos ligados à Central Única dos Trabalhadores (CUT) foram sendo debilitados pela perda crescente de membros, decorrente principalmente da redução dos postos de trabalho e do movimento de terceirização, e pela dificuldade de mobilização de suas bases, expressa na queda do número de greves, bem como na redução de sua duração e extensão ao longo da década.

O objetivo deste artigo é discutir os impactos do processo de reestruturação da indústria metalmecânica e química e do setor bancário na região de Campinas sobre os trabalhadores destes setores e sobre a atuação e o poder de barganha dos sindicatos que os representam, enfocando principalmente, de uma perspectiva comparativa, os processos de negociação coletiva ocorridos no decorrer da década de 90. Estes setores foram escolhidos por estarem entre os mais importantes na região, ${ }^{2}$ tanto do ponto de vista do seu impacto econômico (rentabilidade, volume de negócios) quanto do volume do emprego, mas também pelo fato de os sindicatos a eles vinculados estarem ligados à CUT e se destacarem no movimento sindical da região pela sua combatividade.

\section{A reestruturação nas indústrias metal-mecânica e química}

O setor metal-mecânico foi pioneiro, no Brasil, na introdução de novas tecnologias e das novas práticas de gestão identificadas com o "modelo japonês". O processo de mudanças iniciou-se no final dos anos 70 com a adoção dos Círculos de Controle de Qualidade (CCQ), em resposta a uma situação econômica recessiva e à crescente mobilização dos trabalhadores neste setor. Mas é a partir de meados da década de 80 , com a retomada do crescimento econômico, que observamos uma maior presença, ainda que seletiva e pontual, nas indústrias do setor, de equipamentos de automação microeletrônica, principalmente máquinas-ferramentas de controle numérico computadorizado (CNC), bem como a adoção crescente dos Programas de Qualidade Total e o uso, ainda que locali- zado, de técnicas de programação e controle da produção como o just-in-time e o kanban (Leite, 1994).

Nos anos 80, portanto, a reestruturação realizou-se como um processo defensivo. A racionalização das empresas deu-se via inovações organizacionais e investimentos em "gargalos" da produção e concentrou-se no complexo automotivo. Apenas a partir do final da década foi possível encontrar "um conjunto cada vez maior de empresas em processo de profunda reestruturação a partir de uma decisão da direção, introduzindo um conjunto de inovações articuladas entre si", em geral, a partir da introdução de algum tipo de Programa de Qualidade Total (Araújo e Gitahy, 1998).

Por essa época inicia-se também o processo de certificação de fornecedores e intensifica-se a externalização dos serviços de apoio, como alimentação, limpeza, vigilância etc.

A introdução deste conjunto de inovações tem impactos importantes nas políticas de gestão do trabalho. Principalmente nas empresas de ponta dos setores automotivo e de máquinas, já é possível observar esforços iniciais de redução dos níveis hierárquicos e mudança de postura das chefias, o aumento dos requisitos de escolaridade e a introdução de programas participativos.

No entanto, como observam vários autores que estudaram este período (Carvalho e Schmitz, 1990; Humphrey, 1993; Posthuma, 1995), estaria havendo uma "brasilianização" do uso das técnicas japonesas, que seria responsável pelas mudanças pouco significativas na organização do trabalho no país. Salerno (1993), por exemplo, chama a atenção para a rígida divisão do trabalho, a padronização e definição individual de tarefas e a ausência de autonomia dos trabalhadores que acompanhavam, em várias empresas, a introdução do just-intime e do sistema de células.

Nos anos 90, sob o incentivo da abertura de mercado, da pressão pela modernização das empresas e das políticas neoliberais inauguradas pelo governo Collor de Mello e adotadas como orientação predominante principalmente a partir de 1994, a reestruturação se generaliza nas cadeias produtivas do setor metal-mecânico, com a intensificação do movimento pela qualidade. 
Na região de Campinas, o setor metal-mecânico engloba principalmente as indústrias de autopeças (que concentra o maior número de empresas e de trabalhadores), de máquinas-ferramentas, de aparelhos domésticos de linha branca e de computadores. Estudos realizados sobre o setor na região ${ }^{3}$ mostram que nos anos 80 teve início um processo de desverticalização das grandes empresas e de criação de uma rede de pequenas empresas, estimulada, em grande parte, pelo movimento de externalização de atividades produtivas.

O movimento de reorganização das empresas da região de Campinas aprofundou-se ao longo da década de 90 por meio do aumento dos investimentos na automação do processo produtivo, através da utilização mais generalizada de máquinas CNC, computadores e sistemas CAD/CAM, e da introdução de novos métodos de gestão da produção e do trabalho, como a implantação de células e minifábricas, a adoção dos programas de melhorias contínuas e a generalização do just-in-time interno e do kanban. Estas mudanças acarretaram uma redefinição na divisão e no conteúdo do trabalho, com maior ênfase na multifuncionalidade do trabalhador da produção, para o qual foram transferidas atividades mais rotineiras de manutenção e de controle da qualidade. Isto implicou a construção de um novo perfil de trabalhador e mudanças nas políticas de gestão de recursos humanos, como a elevação dos requisitos de escolaridade como critério de seleção e recrutamento, a organização de programas de treinamento e a introdução de programas participativos visando a um maior envolvimento dos trabalhadores com os objetivos da empresa, bem como a introdução de novas estruturas de cargos e salários e de programas de participação nos resultados (Araújo e Gitahy, 1998).

O aprofundamento do processo de terceirização ${ }^{4}$ das atividades produtivas foi o resultado da reestruturação das grandes empresas, na qual focalização, flexibilização e redução de custos apareceram fortemente associados ao movimento pela qualidade. A externalização de atividades produtivas e auxiliares (alimentação, vigilância, transporte, limpeza etc.) logo tornou-se um fenômeno generalizado, afetando não somente grandes, como também pequenas e médias empresas (Gitahy, Cunha, Previtalli e Rachid, 1997).

A introdução deste conjunto de inovações também teve impacto importante sobre a estrutura do emprego, tanto no interior das empresas, onde as mudanças no conteúdo e na organização do trabalho levaram à redefinição das habilidades e qualificações e à elevação da produtividade com uma redução expressiva do volume do emprego, quanto entre elas, uma vez que os processos de certificação de fornecedores e de terceirização levaram a uma redefinição da estrutura do emprego na cadeia produtiva.

$\mathrm{Na}$ região de Campinas, assim como em outros lugares, este processo de reestruturação deuse, no entanto, de forma contraditória e heterogênea, tanto no interior das grandes empresas quanto ao longo das cadeias produtivas. Nas grandes e em parte das médias empresas, onde o processo de reestruturação se deu de forma mais extensa, por meio de um conjunto integrado de inovações tecnológicas e gerenciais, ainda é possível observar a convivência, na mesma planta, de setores cujo ambiente e processo de trabalho foram modificados pela introdução de novos equipamentos, de novos métodos de gestão e pelo trabalho em grupo, com outros nos quais predominam equipamentos antigos e formas de organização do trabalho que mantêm o trabalho repetitivo e monótono, cujo ritmo intenso é, muitas vezes, controlado pela cadência de uma esteira rolante. Esta mesma diferenciação pode ser encontrada ao longo das cadeias produtivas e das redes de subcontratação. Um conjunto maior de mudanças pode ser verificado nas grandes empresas, na ponta da cadeia, ao passo que ao longo dela observa-se uma gradação que combina o novo e o velho em termos de tecnologia e de formas de organização do processo de trabalho. A presença de aparatos produtivos com baixo conteúdo tecnológico e de práticas tayloristas envolvendo o uso intensivo de mão-de-obra pouco qualificada torna-se mais significativa à medida que nos aproximamos dos níveis "inferiores" da cadeia de fornecedores.

A contraditoriedade deste processo expressa-se, igualmente, na combinação de efeitos qualificadores sobre o trabalho, principalmente nas 
empresas de ponta - que transferem para os trabalhadores maiores responsabilidades na condução do processo produtivo e buscam seu envolvimento e participação - com uma significativa intensificação do ritmo de trabalho, o aumento do desemprego, a precarização das condições e relações de emprego, bem como a degradação das condições de saúde, principalmente quando nos deslocamos para os sucessivos níveis "inferiores" da cadeia produtiva (Leite e Rizek, 1998; Abramo, 1998).

\section{A reestruturação no setor químico}

O setor químico implantou-se no Brasil como um parque produtor de insumos básicos destinados a cobrir um dos principais pontos de estrangulamento de uma industrialização baseada na "substituição de importações”. Na região de Campinas, o parque químico e petroquímico conta com 240 fábricas, das quais 25 representam os setores de química fina, abrasivos e farmacêutico e são responsáveis por quase $90 \%$ da produção. O restante, em geral pequenas empresas, representa principalmente a indústria de plástico, de produtos para limpeza, desinfetantes, inseticidas etc. Este parque teve um crescimento significativo na década de 80, decorrente da expressiva interiorização da indústria química do Estado de São Paulo, o que possibilitou que o setor alcançasse, nos anos 90, um patamar três quartos superior àquele do início da década anterior. Campinas hoje lidera a produção no interior paulista no que diz respeito ao valor gerado pelas indústrias farmacêuticas, de produtos plásticos e de borracha (Silva, 1997).

Como dependeu, em geral, da aquisição de pacotes desenvolvidos no exterior, o progresso técnico neste setor ocorreu de modo muito lento. No início da década de 70 , a indústria química brasileira ainda estava baseada numa tecnologia pneumática de controle de processo que se mantinha estável desde os anos 50. Sob pressão da crise econômica, ela foi desafiada a aumentar sua eficiência produtiva e já a partir de meados dos anos 80 as empresas começaram a se reestruturar e a seguir as tendências internacionais de modo a poderem se manter competitivas. As transformações de maior repercussão foram as decorrentes da introdução da automação microeletrônica para o aprimoramento de processos, já que o ritmo da produção, neste tipo de indústria , não depende totalmente do ritmo do trabalho, mas da produtividade resultante do rendimento global das instalações, da perfomance dos equipamentos e da redução do número de horas paradas para sua manutenção.

Assim, as mudanças nas indústrias químicas resultaram, inicialmente, num esforço generalizado de renovação tecnológica pela introdução dos Sistemas Digitais de Controle Distribuído (SDCD), que podiam ser acoplados a computadores para agilizar o envio de dados na análise do processamento (Castro e Guimarães, 1991; Rizek, 1994). Após a substituição dos equipamentos obsoletos, seguiu-se a implantação dos programas de controle avançado e da otimização on line, para racionalizar custos (especialmente no balanço energético) e atingir padrões técnicos mais estáveis, adquirindo condição para atuar no mercado exportador.

Com a introdução do SDCD, parte do controle humano cedeu lugar a formas de controle mais eficientes e rigorosas, através desses equipamentos microeletrônicos. Os operadores passaram a operar simultaneamente várias máquinas e, a partir de um único painel, a controlar, por exemplo, o volume, temperatura e pressão de vários compartimentos. Estas mudanças, aliadas a modificações nas estruturas administrativas, trouxeram impactos negativos sobre o emprego, atingindo primeiramente os operadores menos experientes, cuja atividade se restringia à operação de campo (Castro e Guimarães, 1991).

Na busca de melhor qualidade e produtividade e da redução dos custos associados à produção, a renovação tecnológica foi acompanhada da adoção de novas práticas de gestão, com a introdução de Programas de Qualidade Total, do CEP (Controle Estatístico de Processo), assim como de mudanças na organização da produção, com a formação de "grupos de trabalho" e a redução de níveis hierárquicos. Observa-se um incremento da focalização da produção para permitir maior integração entre as áreas e a externalização de atividades (Castro, 1998).

$\mathrm{Na}$ década de 90, com a intensificação da abertura comercial e a reorientação das políticas 
econômica e industrial brasileiras, as indústrias químicas - que se haviam beneficiado por muito tempo de um mercado protegido - viram-se expostas à competição internacional e passaram a se preocupar de forma mais profunda com a reestruturação e em melhorar a qualidade de seus produtos. No entanto, grande parte das empresas respondeu a esta situação com estratégias de ajuste defensivo, concentrando esforços em medidas que visavam a redução de custos a curto prazo. As despesas com pessoal foram fortemente reduzidas mediante demissões, cortes de salários e eliminação de níveis hierárquicos, o que levou a uma intensificação da adoção de novas estratégias organizacionais e de aproveitamento de mão-de-obra "sobrevivente" (Castro, 1998; Druck, 1999).

Apesar da recuperação da economia mundial e da estabilização econômica do país no biênio 1994-1995, que permitiram o reaquecimento das indústrias química e petroquímica domésticas, as empresas procuraram manter os resultados do ajuste defensivo efetuado: as estruturas de $P \& D$ não foram reconstituídas e o nível de emprego mantevese estacionado em um patamar baixo. As decisões de investimentos para aumento da capacidade produtiva foram marginais e resultaram apenas em introduções pontuais de novos equipamentos.

Observou-se, ainda, a ampliação das iniciativas de terceirização, atingindo crescentemente o setor de manutenção (Druck, 1997 e 1999). Reduziu-se o número de trabalhadores empregados diretamente e acelerou-se a implantação de programas de melhoria contínua, do trabalho em grupo e dos chamados "programas participativos". Tudo isso gerou uma mudança no perfil da categoria. Passou-se a exigir uma maior "polivalência" dos trabalhadores, maior responsabilidade e autonomia no "gerenciamento" da produção, e a privilegiar o estreitamento de relações entre operários e chefias. Estes mecanismos permitiram a eliminação de vários cargos (principalmente postos de supervisão) e a redução do número de trabalhadores nos laboratórios, com a transferência de partes mais simples das análises para os operadores de campo. Tais mudanças desencadearam também uma "reestruturação das carreiras" que, segundo Castro (1998), envolveu uma reorganização das tarefas, gerando alterações importantes nas estratégias de tomada de decisões e no perfil interno das empresas, com a redistribuição do efetivo já existente.

Como no setor metalúrgico, o processo de modernização no complexo químico deu-se de forma heterogênea no interior das grandes empresas, entre seus diferentes subsetores, bem como ao longo da cadeia produtiva (Castro, 1998; Druck, 1999). A indústria de plásticos, composta por um grande número de pequenas empresas que pagam os salários mais baixos do setor químico, é uma das pontas desta cadeia, na qual a reestruturação vem ocorrendo de forma mais lenta e restritiva, movida pela redução de custos a curto prazo. Neste setor ${ }^{5}$ é possível observar ainda uma grande presença de equipamentos obsoletos e o predomínio de formas tayloristas de organização do trabalho, baseadas no controle autoritário das chefias. A introdução de alguns dos novos métodos de gestão, como células ou times de produção, e a agregação de tarefas nos postos da produção têm levado a uma intensificação do ritmo de trabalho, em ambientes muitas vezes insalubres, acarretando um aumento dos casos de doenças ocupacionais como as LER.

\section{A reestruturação no setor bancário brasileiro}

O setor bancário brasileiro iniciou seu processo de automação no final da década de 60, através da introdução dos Centros de Processamento de Dados, que alteraram a rotina dos serviços de retaguarda dos bancos. Este processo teve continuidade nos anos 70, mas foi nos anos 80 que os sistemas automatizados alcançaram o atendimento ao público, inicialmente nos bancos privados e, mais no final da década, também nos bancos públicos (Blass, 1993). Os lucros auferidos pelos bancos neste período, em função das altas taxas inflacionárias, foram muito importantes para o investimento maciço e generalizado em automação ocorrido em todo o setor. Desse modo, a partir do final dos anos 80 , generalizaram-se no país as agências on-line, o uso dos caixas automáticos, os bancos eletrônicos e os bancos 24 horas.

Na década de 90, com a crescente concentração do capital financeiro e a desregulamentação do 
mercado decorrentes do papel central adquirido pelo sistema financeiro na nova dinâmica do capitalismo, o sistema bancário perdeu o monopólio sobre o crédito e o sistema de pagamentos e, em conseqüência, a concorrência tornou-se muito mais acirrada (Braga, 1993, p. 47).

A inserção do Brasil neste novo quadro teve início no governo de Fernando Collor de Mello (1990-1992). A partir de 1995, o governo Fernando Henrique Cardoso deu novo impulso à adoção de medidas neoliberais, acelerando o processo de privatizações e aprofundando a desregulamentação do mercado financeiro. Neste período, a estabilização econômica, que reduziu a rentabilidade dos bancos, e a permissão para o aumento da participação de instituições estrangeiras no país desencadearam a quebra de vários bancos e um processo de fusões/aquisições e de privatizações de bancos públicos, resultando numa concentração do sistema bancário nacional, no interior do qual também ocorreu uma maior concentração de poder por parte dos bancos estrangeiros (Freitas, 1998).

Nesta situação, a reestruturação do sistema bancário tomou um novo rumo. No seu esforço de adaptação ao novo contexto, os bancos modificaram suas estruturas internas, na maioria das vezes, optando pela especialização em certos nichos de mercado, pela venda de uma gama diferenciada de produtos e pela introdução de inovações organizacionais. Em 1994, por exemplo, a Federação Brasileira dos Bancos (Febraban) lançou o projeto "Qualidade em Atendimento", que orientava os bancos para o oferecimento de um atendimento personalizado aos seus clientes, principalmente aos considerados especiais. Suas diretrizes sugeriam a revisão do layout das agências, a diminuição das filas, o recurso ao marketing, a melhor utilização da estrutura tecnológica instalada, combinada com investimentos em formação e treinamento dos funcionários.

Seguindo essas orientações, na segunda metade dos anos 90, a principal inovação promovida pela maioria dos bancos foi a passagem de uma estratégia baseada na aquisição de clientes (segundo a lógica da quantidade) para uma baseada no cultivo de clientes (segundo a lógica da qualidade), cujo objetivo passou a ser o da captação do maior volume possível de recursos. Com isso, o layout das agências foi modificado, os bancários (que passaram a ser considerados "polivalentes") tornaram-se também vendedores de diversos produtos, tais como títulos de capitalização, cartões de créditos e seguros, e sua atenção voltou-se para os clientes médios e grandes, potencialmente investidores. Na busca de uma maior produtividade do trabalho, o conceito de qualidade total, o trabalho em equipe e as metas de desempenho passaram a fazer parte da rotina dos bancários.

Assim, os investimentos em gestão vieram complementar aqueles realizados em automação desde o final dos anos 60. Segundo dados da Febraban, os investimentos em tecnologia, que chegaram a US\$ 4,1 bilhões em 1994, caíram para US\$ 1 bilhão em 1995, enquanto os investimentos em formação e treinamento de funcionários, ainda que muito menos vultosos, tiveram um aumento de 100\% entre 1993 e 1996 (Febraban, 1994; Larangeira, 1997).

Conseqüências importantes deste processo, o fechamento de um grande número de agências, o enxugamento das que restaram e a intensificação da terceirização de serviços bancários modificaram profundamente a configuração do setor e tiveram impacto decisivo sobre o emprego, alterando o tamanho e o perfil da categoria bancária. ${ }^{6}$

\section{Impactos da reestruturação sobre os trabalhadores e sobre os sindicatos}

Analisando comparativamente a reestruturação nos três setores, percebemos que tanto o setor bancário quanto o químico apresentaram, nos anos 80 e início dos 90, um movimento mais acentuado de automação, com a introdução de equipamentos microeletrônicos e sistemas digitais. Também no setor metal-mecânico verifica-se uma intensificação da introdução novas tecnologias, mas que aparece associada ao início de um movimento pela qualidade, e da adoção de novos métodos de gestão da produção, como o CEP, o just-in-time o kanban. Nos anos 90, o processo de reestruturação se aprofunda e se generaliza nos três setores. Há uma contínua expansão da modernização tecnológica, mas o foco do processo de mudanças desloca-se para as inovações gerenciais, principalmente medi- 
ante a adoção de Programas de Qualidade Total, em geral associados ao estabelecimento de metas de desempenho, dos grupos de trabalho, de programas de formação e treinamento e de programas de incentivo à participação dos trabalhadores.

O enxugamento das grandes fábricas e bancos e a utilização da terceirização em larga escala foram características fundamentais da reestruturação nos anos 90. No início da década, a terceirização se limitava, nos três setores estudados, às áreas de apoio, como alimentação, limpeza, vigilância e transporte. Já em meados da década ela atingiu as chamadas atividades-fim das empresas: setores de produção, como usinagem, ferramentaria, fabricação de peças e montagens de subconjuntos integrados, na indústria metal-mecânica; a produção de alguns insumos e a área de manutenção no setor químico; centros de processamento de dados (CPDs), compensação e microfilmagem de cheques, digitação, atendimento de portaria e substituição dos escriturários, no caso dos bancos. Conjuntamente, esses dois processos levaram, nos setores estudados, a demissões em massa e à proliferação de pequenos estabelecimentos.

Além disso, o processo de reestruturação teve como conseqüência uma mudança significativa no perfil da mão-de-obra que permaneceu empregada e a ampliação da heterogeneidade interna entre os trabalhadores. A introdução deste conjunto de mudanças tecnológicas e organizacionais afetou a estrutura do emprego nos três setores estudados, modificando a divisão e o conteúdo do trabalho e redefinindo as qualificações dos trabalhadores.

No que se refere ao volume do emprego, verificou-se, no setor metal-mecânico, uma redu- ção importante de postos de trabalho, que ocorreu paralelamente a uma elevação da produtividade e do faturamento das empresas. A elevação da produtividade está associada tanto à difusão das inovações tecnológicas e organizacionais ao longo das cadeias produtivas quanto ao movimento de terceirização de atividades, que promove uma redefinição da divisão do trabalho entre as empresas da cadeia. Estes dois movimentos provocam uma enorme redução do emprego em números absolutos e relativos e a mudança na distribuição do emprego entre empresas de portes diferentes.

Na região de Campinas, o número de empregos na indústria metalúrgica passou de 63.554, em 1986, para 46.390 em 1997, o que corresponde a uma redução de 17.164 postos de trabalho (27\%) (ver Tabela 1). Verifica-se também mudança significativa na distribuição do emprego, com seu deslocamento para empresas de menor porte, em função da intensificação do processo de terceirização e do enxugamento das grandes empresas. Assim, de acordo com os dados da Tabela 2, se em 1986 somente $27,9 \%$ dos trabalhadores metalúrgicos trabalhavam em empresas de até 249 funcionários, em 1997 eles correspondiam a 46,2\% do emprego total no setor, ao passo que nas empresas com mais de mil empregados, que concentravam 50\% do emprego em 1987, ocorreu o movimento inverso, pois apenas $26 \%$ dos trabalhadores estavam empregados nestas empresas em 1997.

No setor químico não ocorreu uma redução significativa de postos de trabalho nos últimos anos. Ao contrário, ocorreram oscilações no emprego e um crescimento do número de trabalhadores, que passou de $11.072 \mathrm{em} 1986$ para $14.116 \mathrm{em}$ 1997, um acréscimo de 27,5\% (Tabela 1).

Tabela 1

Evolução do Emprego entre Químicos, Metalúrgicos e Bancários da Região de Campinas (1986-1997)

\begin{tabular}{lcccccccccc}
\hline \multicolumn{10}{c}{ Anos } \\
\hline Categorias & 1986 & 1989 & 1990 & 1991 & 1992 & 1993 & 1994 & 1995 & 1996 & 1997 \\
\hline Químicos & 11.072 & 13.542 & 12.780 & 12.524 & 11.905 & 12.719 & 15.223 & 14.466 & 14.095 & 14.116 \\
Metalúrgicos & 63.554 & 71.095 & 62.929 & 57.502 & 50.591 & 49.600 & 55.059 & 49.570 & 43.919 & 46.390 \\
Bancários & 15.038 & 16.609 & 14.774 & 13.819 & 13.011 & 13.378 & 11.023 & 11.373 & 9.849 & 9.007 \\
\hline
\end{tabular}

Fonte: Elaboração própria a partir do banco de dados da RAIS/Ministério do Trabalho. 
Tabela 2

\section{Evolução do Emprego por Porte da Empresa entre os Metalúrgicos e Químicos da Região de Campinas (1986-1997)}

\begin{tabular}{|c|c|c|c|c|c|c|c|c|c|c|}
\hline \multirow{4}{*}{$\overline{\text { Anos }}$} & \multicolumn{10}{|c|}{ Número de Empregados } \\
\hline & \multicolumn{5}{|c|}{ Metalúrgicos (\%) } & \multicolumn{5}{|c|}{ Químicos (\%) } \\
\hline & De 1 & De 50 & De 250 & De 500 & 1000 & De 1 & De 50 & De 250 & De 500 & 1000 \\
\hline & a 49 & a 249 & a 499 & a 999 & ou mais & a 49 & a 249 & a 499 & a 999 & ou mais \\
\hline 1986 & 8,8 & 19,1 & 9,9 & 12,5 & 49,6 & 13,4 & 29,6 & 22,0 & 0,0 & 35,0 \\
\hline 1987 & 8,7 & 17,4 & 12,0 & 11,8 & 50,1 & 12,3 & 29,7 & 23,7 & 0,0 & 34,2 \\
\hline 1988 & - & - & - & - & - & 10,6 & 29,6 & 25,1 & 4,1 & 30,5 \\
\hline 1989 & 9,0 & 17,3 & 13,5 & 12,1 & 47,9 & 10,7 & 33,7 & 23,4 & 3,7 & 30,4 \\
\hline 1990 & 10,8 & 18,4 & 11,8 & 11,9 & 48,0 & 10,2 & 32,5 & 21,9 & 4,3 & 28,4 \\
\hline 1991 & 10,1 & 20,0 & 11,8 & 11,7 & 47,1 & 10,4 & 36,2 & 13,9 & 8,7 & 30,3 \\
\hline 1992 & 10,4 & 19,9 & 11,0 & 10,4 & 48,2 & 12,8 & 36,4 & 18,5 & 4,5 & 29,8 \\
\hline 1993 & 11,7 & 21,7 & 8,2 & 12,2 & 46,2 & 12,3 & 34,5 & 21,3 & 8,9 & 27,8 \\
\hline 1994 & 13,5 & 21,7 & 12,4 & 12,0 & 40,3 & 14,7 & 34,6 & 23,9 & 7,0 & 23,5 \\
\hline 1995 & 18,4 & 24,8 & 9,9 & 16,4 & 32,4 & 13,9 & 38,0 & 24,2 & 3,8 & 19,9 \\
\hline 1996 & 17,7 & 26,3 & 12,8 & 14,0 & 28,3 & 14,6 & 41,2 & 17,1 & 7,6 & 19,4 \\
\hline 1997 & 19,6 & 26,6 & 12,9 & 18,1 & 26,1 & 14,7 & 41,7 & 11,6 & 11,7 & 20,3 \\
\hline
\end{tabular}

Fonte: Elaboração própria a partir do banco de dados da RAIS/Ministério do Trabalho.

Este aumento do emprego em Campinas, no mesmo período em que o emprego no conjunto da cadeia petroquímica reduziu-se de modo significativo no país, indica que esta é uma região de relocalização do emprego neste setor. Este crescimento deveu-se principalmente à expansão dos setores farmacêutico e de plástico, ${ }^{7}$ correspondendo também ao aumento das pequenas empresas.

No caso da indústria química, por ser um setor de capital intensivo, a introdução de novos equipamentos não teve um impacto tão decisivo sobre o volume do emprego. No pólo químico de Campinas, a elevação da produtividade e a reorganização da composição do emprego ao longo da cadeia parecem estar associadas não só à inovação tecnológica, mas também ao intenso movimento de terceirização de serviços e atividades produtivas.

Como se pode observar na Tabela 2 , o número de trabalhadores empregados nas empresas deste setor com até 249 empregados sobe de 43\%, em 1986, para 56,4\% em 1997. Mas é nas empresas que empregam de 100 a 249 trabalhadores que o aumento do emprego foi mais significativo: a porcentagem de trabalhadores do setor empregados neste tipo de empresa passou de 19,4\%, em 1986, para 30,3\% em 1997. Em contraposição, o emprego diminuiu de modo significativo nas empresas com 250 a 499 empregados, passando de 22\% em 1986 para 11,6\% em 1997, e naquelas com mais de mil trabalhadores, nas quais a proporção do emprego caiu de $35 \%$ para $20,3 \%$ no período.

Apesar de a direção do Sindicato dos Químicos de Campinas perceber a redução do emprego como uma das causas centrais da redução de sua capacidade de mobilização e do seu poder de barganha, esses efeitos não se devem a uma perda quantitativa de postos de trabalho na categoria como um todo. Provavelmente, eles se devem ao enxugamento das grandes empresas, onde o sindicato tem maior penetração e um maior número de sindicalizados, mas também ao deslocamento do emprego para as empresas de menor porte, nas quais os sindicalistas encontram maior dificuldade em organizar e representar os trabalhadores, devido à presença, em muitas delas, de chefias autoritárias e pouco dispostas a negociar.

A reestruturação do setor bancário foi acompanhada, nos anos 90, de um grande enxugamento 
dos bancos, com grande redução do emprego. Se nos anos 80 o emprego cresceu de 15.038 empregados em 1986 para 16.609 em 1989 (apesar da intensificação do processo de automação), na década de 90 verificou-se uma perda de cerca de $40 \%$ dos postos de trabalho, que chegaram a $9.007 \mathrm{em}$ 1997 (ver Tabela 1).

Nos bancos, a tendência de deslocamento do emprego para estabelecimentos de menor porte ocorre de forma ainda mais significativa, pois os estabelecimentos com mais de 500 funcionários, que detinham 14,8\% do total do emprego em 1985 , desaparecem na região de Campinas a partir de 1996. Em compensação, os estabelecimentos com até 49 empregados, que em 1986 detinham 38,5\% do total do emprego no setor, passaram a represen$\operatorname{tar}$ 66,4\% desse total em 1997, mostrando a existência de um processo de enxugamento das grandes agências, o impacto do desaparecimento dos grandes centros de processamento de dados e a intensificação do processo de terceirização dos serviços bancários nos anos 90 (Tabela 3).

Tabela 3

Evolução do Emprego por Porte da Empresa entre os Bancários da Região de Campinas (1986-1997)

$(\%)$

\begin{tabular}{lcccc}
\hline \multicolumn{5}{c}{$N^{o}$ de Empregados } \\
\hline Anos & Até & De 50 & De 250 & 500 \\
& 49 & a 249 & a 499 & ou mais \\
\hline 1986 & 38,58 & 41,34 & 5,23 & 14,85 \\
1989 & 36,32 & 37,20 & 6,95 & 19,53 \\
1990 & 42,46 & 34,41 & 8,03 & 15,10 \\
1991 & 46,85 & 28,40 & 10,82 & 13,93 \\
1992 & 45,81 & 29,36 & 15,24 & 9,59 \\
1993 & 47,48 & 24,43 & 15,59 & 12,51 \\
1994 & 51,65 & 24,96 & 12,30 & 11,09 \\
1995 & 51,26 & 22,69 & 20,13 & 5,92 \\
1996 & 57,23 & 22,43 & 20,34 & 0,00 \\
1997 & 66,40 & 23,17 & 10,43 & 0,00 \\
\hline
\end{tabular}

Fonte: Elaboração própria a partir do banco de dados da RAIS/Ministério do Trabalho.

A reorganização do trabalho no interior das fábricas e dos bancos tem provocado mudanças significativas na composição da mão-de-obra, como um processo de feminização crescente e o predomínio de uma mão-de-obra mais escolarizada e com maior estabilidade. Os dados da Tabela 4 mostram uma elevação da escolaridade em todos os níveis, destacando-se o crescimento da proporção de tra-

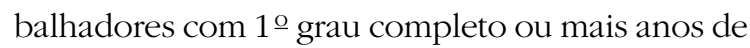
escolaridade, que passa de 37,1\% em 1986 para 64,7\% em 1997 no setor metalúrgico, e de 47,2\% para $70,6 \%$, no mesmo período, na indústria quími-

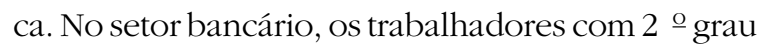
completo ou mais passam de 63\% em 1986 para $82 \%$ em 1997. Estes dados refletem, por um lado, a exigência desse nível de escolaridade como critério de recrutamento e os efeitos dos programas de treinamento que proliferaram nas empresas e bancos ao longo do período e, por outro, a seletividade das empresas nos processos de demissão, cortando os trabalhadores menos escolarizados.

Cabe destacar, nos três setores estudados, a redução da rotatividade, que se reflete na evolução da distribuição do emprego por tempo de serviço (Tabela 5). Na indústria metal-mecânica, os trabalhadores com três anos ou mais de permanência na empresa passam de 36,6\% em 1986 para 48,6\% em 1997, e a categoria com até 2,9 meses de permanência (que oculta o uso de trabalho temporário para enfrentar picos de produção) passa de 63,5\% em 1986 para 51\% em 1997. No setor bancário, a estabilização da mão-de-obra parece ter ocorrido de forma ainda mais acentuada, pois os bancários que têm mais de cinco anos de serviço passaram de $42,4 \%$ para $73,9 \%$ do conjunto dos trabalhadores do setor entre 1986 e 1997.

A indústria química diferencia-se dos outros dois setores, pois nela os trabalhadores com três anos ou mais de permanência no emprego mantêm, no período, a mesma participação de cerca de $47 \%$, enquanto os que têm de 1 a 2,9 anos de permanência apresentaram um aumento mais significativo — de 21,2\% em 1986 para 27,6\% em 1997 —, refletindo o processo de relocalização e expansão recente do emprego, principalmente em novas empresas que se instalaram na região.

Finalmente, cabe destacar a ocorrência de um processo de feminização nos três setores. De 1986 a 1997, a participação feminina cresceu de $12,8 \%$ para $14,2 \%$ entre os metalúrgicos, de 40,84\% 
Tabela 4

Evolução do Emprego por Escolaridade entre os Metalúrgicos, Químicos e Bancários de Campinas (1986-1997)

\begin{tabular}{|c|c|c|c|c|c|c|c|c|c|c|c|c|}
\hline & \multicolumn{12}{|c|}{ Escolaridade } \\
\hline & \multicolumn{4}{|c|}{ Metalúrgicos (\%) } & \multicolumn{4}{|c|}{ Químicos (\%) } & \multicolumn{4}{|c|}{ Bancários (\%) } \\
\hline Anos & $\begin{array}{c}\text { Até } \\
1 \text { o grau } \\
\text { incom- } \\
\text { pleto }\end{array}$ & $\begin{array}{l}\text { De } 1^{\circ} \text { grau } \\
\text { incom- } \\
\text { pleto } \\
\text { até } \\
2^{\circ} \text { grau } \\
\text { incom- } \\
\text { pleto }\end{array}$ & $\begin{array}{c}\text { De } \\
2^{\mathrm{o}} \text { grau } \\
\text { completo } \\
\text { até } \\
\text { superior } \\
\text { incom- } \\
\text { pleto }\end{array}$ & $\begin{array}{l}\text { Superior } \\
\text { completo }\end{array}$ & $\begin{array}{c}\text { Até } \\
\text { 1ㅇ grau } \\
\text { incom- } \\
\text { pleto }\end{array}$ & $\begin{array}{l}\text { De } 10 \text { grau } \\
\text { incom- } \\
\text { pleto } \\
\text { até } \\
2 \text { o grau } \\
\text { incom- } \\
\text { pleto }\end{array}$ & $\begin{array}{c}\text { De } \\
2^{\text {o grau }} \\
\text { completo } \\
\text { até } \\
\text { superior } \\
\text { incom- } \\
\text { pleto }\end{array}$ & $\begin{array}{l}\text { Superior } \\
\text { completo }\end{array}$ & $\begin{array}{c}\text { Até } \\
\text { 10 grau } \\
\text { incom- } \\
\text { pleto }\end{array}$ & $\begin{array}{l}\text { De } 1 \text { o grau } \\
\text { incom- } \\
\text { pleto } \\
\text { até } \\
2 \text { o grau } \\
\text { incom- } \\
\text { pleto }\end{array}$ & $\begin{array}{c}\text { De } \\
2^{\circ} \text { grau } \\
\text { completo } \\
\text { até } \\
\text { superior } \\
\text { incom- } \\
\text { pleto }\end{array}$ & $\begin{array}{l}\text { Superior } \\
\text { completo }\end{array}$ \\
\hline 1986 & 62,6 & 20,2 & 12,0 & 4,9 & 52,3 & 21,4 & 17,1 & 8,7 & 6,57 & 30,34 & 48,60 & 14,57 \\
\hline 1989 & 60,1 & 22,5 & 11,7 & 5,4 & 48,6 & 23,9 & 21,1 & 9,1 & 6,05 & 30,11 & 49,47 & 14,26 \\
\hline 1990 & 58,5 & 23,0 & 11,2 & 6,0 & 42,9 & 24,1 & 21,0 & 11,8 & 5,36 & 27,61 & 49,75 & 17,23 \\
\hline 1991 & 56,1 & 24,0 & 12,9 & 6,9 & 40,7 & 25,6 & 21,6 & 12,2 & 4,70 & 25,44 & 51,15 & 18,70 \\
\hline 1992 & 54,0 & 24,4 & 12,8 & 6,7 & 38,2 & 25,2 & 22,0 & 13,6 & 3,67 & 24,20 & 50,98 & 20,11 \\
\hline 1993 & 50,8 & 29,4 & 13,0 & 5,7 & 38,3 & 26,2 & 21,9 & 12,8 & 3,83 & 21,73 & 52,19 & 21,03 \\
\hline 1994 & 48,9 & 30,2 & 14,1 & 6,9 & 39,1 & 25,6 & 22,5 & 12,8 & 5,81 & 21,89 & 48,83 & 23,48 \\
\hline 1995 & 44,8 & 31,5 & 17,0 & 6,7 & 36,0 & 26,2 & 24,1 & 13,2 & 2,91 & 32,40 & 46,41 & 18,28 \\
\hline 1996 & 40,6 & 34,0 & 18,9 & 6,5 & 33,1 & 26,6 & 25,9 & 14,3 & 3,70 & 15,62 & 54,18 & 26,51 \\
\hline 1997 & 35,2 & 35,8 & 20,8 & 8,1 & 29,3 & 27,4 & 28,2 & 15,0 & 2,55 & 15,22 & 54,17 & 28,06 \\
\hline
\end{tabular}

Fonte: Elaboração própria a partir do banco de dados da RAIS/Ministério do Trabalho.

Tabela 5

Evolução do Emprego segundo o Tempo de Serviço entre os Metalúrgicos, Químicos e Bancários da Região de Campinas (1986-1997)

\begin{tabular}{|c|c|c|c|c|c|c|c|c|c|c|c|c|}
\hline & \multicolumn{12}{|c|}{ Tempo de Serviço } \\
\hline & \multicolumn{4}{|c|}{ Metalúrgicos (\%) } & \multicolumn{4}{|c|}{ Químicos (\%) } & \multicolumn{4}{|c|}{ Bancários (\%) } \\
\hline Anos & $\begin{array}{l}\text { Até } \\
1 \text { ano }\end{array}$ & $\begin{array}{l}\text { De } 1 \mathrm{a} \\
2,9 \text { anos }\end{array}$ & $\begin{array}{c}\text { De } 3 \text { a } \\
4,9 \text { anos }\end{array}$ & $\begin{array}{c}5 \text { anos } \\
\text { ou mais }\end{array}$ & $\begin{array}{l}\text { Até } \\
1 \text { ano }\end{array}$ & $\begin{array}{c}\text { De } 1 \text { a } \\
2,9 \text { anos }\end{array}$ & $\begin{array}{c}\text { De } 3 \text { a } \\
4,9 \text { anos }\end{array}$ & $\begin{array}{l}5 \text { anos } \\
\text { ou mais }\end{array}$ & $\begin{array}{l}\text { Até } \\
1 \text { ano }\end{array}$ & $\begin{array}{c}\text { De } 1 \text { a } \\
2,9 \text { anos }\end{array}$ & $\begin{array}{c}\text { De } 3 \text { a } \\
4,9 \text { anos }\end{array}$ & $\begin{array}{l}5 \text { anos } \\
\text { ou mais }\end{array}$ \\
\hline 1986 & 34,3 & 29,2 & 6,8 & 29,8 & 30,9 & 21,2 & 8,4 & 39,5 & 19,59 & 27,18 & 11,00 & 42,43 \\
\hline 1989 & 27,2 & 25,3 & 18,5 & 29,1 & 29,0 & 24,5 & 14,2 & 32,1 & 17,17 & 26,46 & 14,95 & 39,64 \\
\hline 1990 & 22,3 & 26,0 & 18,0 & 22,7 & 20,2 & 26,3 & 14,7 & 36,1 & 9,26 & 27,12 & 15,62 & 48,00 \\
\hline 1991 & 18,1 & 27,1 & 15,4 & 39,3 & 22,0 & 23,2 & 16,8 & 40,2 & 10,46 & 20,92 & 17,94 & 50,68 \\
\hline 1992 & 13,3 & 25,5 & 17,6 & 43,6 & 14,3 & 25,8 & 15,9 & 43,0 & 7,97 & 15,85 & 20,18 & 56,01 \\
\hline 1993 & 16,7 & 19,4 & 19,3 & 44,6 & 19,2 & 21,9 & 14,8 & 43,0 & 6,71 & 14,75 & 16,81 & 61,74 \\
\hline 1994 & 20,2 & 18,0 & 16,3 & 45,5 & 23,5 & 20,5 & 12,1 & 41,1 & 8,96 & 13,29 & 14,13 & 63,62 \\
\hline 1995 & 22,1 & 20,8 & 11,0 & 46,0 & 25,6 & 22,4 & 9,8 & 39,9 & 12,47 & 8,31 & 10,31 & 68,91 \\
\hline 1996 & 23,8 & 25,5 & 10,5 & 40,2 & 27,0 & 25,4 & 9,0 & 37,9 & 12,93 & 6,28 & 7,78 & 73,01 \\
\hline 1997 & 28,2 & 22,8 & 11,2 & 37,4 & 25,2 & 27,6 & 11,5 & 35,9 & 15,59 & 4,96 & 5,55 & 73,90 \\
\hline
\end{tabular}

Fonte: Elaboração própria a partir do banco de dados da RAIS/Ministério do Trabalho.

para 49,6\% no sistema bancário de 18,5\% para 23,2\% na indústria química (Tabela 6).

Além disso, no que diz respeito à divisão e conteúdo do trabalho, observamos que, em decorrência do processo de reestruturação, houve uma redução das hierarquias (principalmente níveis intermediários de chefia e supervisão) tanto nos bancos quanto nos dois setores industriais, com a conseqüente agregação de tarefas e de novas responsabilidades aos postos de trabalho. Estes fatores parecem indicar, à primeira vista, uma tendência mais acentuada nos setores estudados para a predominância da multifuncionalidade e para a qualificação dos trabalhadores. No entanto, 
esta tendência supostamente qualificadora precisa ser analisada com mais cuidado.

No caso dos bancários, convém mencionar, em primeiro lugar, que a diminuição do número de escriturários e o aumento da estabilidade no emprego podem significar que foram as funções mais desqualificadas o principal alvo das ondas de demissões implementadas durante a década. No entanto, o desempenho destas funções passou a ser absorvido por outros funcionários, que com esta agregação de funções não se tornaram necessariamente mais qualificados, mas tiveram seu ritmo de trabalho intensificado. Assim, ainda que alguns cargos tenham passado por um processo de qualificação no decorrer da década, como pode ser o caso das gerências, ${ }^{8}$ este processo não se estendeu para a maioria dos bancários, principalmente para digitadores, caixas e aqueles encarregados do primeiro atendimento aos clientes.

\section{Tabela 6 \\ Evolução do Emprego por Gênero entre Metalúrgicos, Químicos e Bancários da Região de Campinas (1986-1997)}

\begin{tabular}{ccc|cc|cc}
\hline \multicolumn{7}{c}{ Sexo } \\
\hline \multicolumn{3}{c}{ Metalúrgicos (\%) } & \multicolumn{2}{c}{ Químicos (\%) } & \multicolumn{2}{c}{ Bancários (\%) } \\
\hline Anos & $\begin{array}{c}\text { Mascu- } \\
\text { nino }\end{array}$ & $\begin{array}{c}\text { Femi- } \\
\text { lino }\end{array}$ & \multicolumn{2}{c}{ Mascu- } & Femi- & \multicolumn{2}{c}{ Mascu- Femi- } \\
nino & lino & \multicolumn{2}{c}{ nino } & lino \\
1986 & 87,2 & 12,8 & 81,5 & 18,5 & 59,16 & 40,84 \\
1989 & 86,5 & 13,5 & 79,7 & 20,3 & 55,45 & 44,55 \\
1990 & 86,3 & 13,7 & 79,3 & 20,7 & 54,28 & 45,72 \\
1991 & 86,5 & 13,5 & 77,9 & 22,1 & 53,32 & 46,68 \\
1992 & 87,0 & 13,0 & 77,1 & 22,9 & 52,75 & 47,25 \\
1993 & 86,9 & 13,1 & 77,4 & 22,6 & 53,27 & 46,73 \\
1994 & 85,4 & 14,6 & 77,2 & 22,8 & 51,74 & 48,26 \\
1995 & 84,6 & 15,4 & 77,0 & 23,0 & 51,31 & 48,69 \\
1996 & 85,1 & 14,9 & 76,5 & 23,5 & 50,99 & 49,01 \\
1997 & 85,8 & 14,2 & 76,8 & 23,2 & 50,35 & 49,65 \\
\hline
\end{tabular}

Fonte: Elaboração própria a partir do banco de dados da RAIS/Ministério do Trabalho.

Por outro lado, a elevação dos níveis de escolaridade, observada de forma significativa entre os bancários, pode significar não uma necessidade para o bom desempenho de cada cargo ou função, mas uma mudança nos critérios de seleção diante da grande disponibilidade de mão-de-obra escolarizada, decorrente das altas e crescentes taxas de desemprego no país. Ou seja, para a categoria bancária, a questão da qualificação parece surgir mais como um discurso destinado a garantir o comprometimento dos funcionários com os objetivos do banco do que como uma prerrogativa ou necessidade real dos novos conteúdos do trabalho.

A exigência, cada vez mais presente nas fábricas e nos bancos, de maior responsabilidade e envolvimento do empregado com a qualidade e as metas de produção ou de vendas tem levado a um acirramento da competitividade entre os trabalhadores, devido à busca do aumento da produtividade do trabalho. A intensificação do ritmo de trabalho e a extensão da jornada de trabalho decorrente deste processo têm resultado em um aumento significativo das doenças ocupacionais na última década, com destaque para as Lesões por Esforços Repetitivos (LER), principalmente entre metalúrgicos e bancários.

Nos anos 80, a redução da jornada de trabalho era uma forte bandeira do movimento sindical na luta por melhores condições de trabalho. Nos anos 90, contrariando as reivindicações dos trabalhadores, ocorreu um aumento na utilização das horas extras, principalmente após as grandes levas de demissões. Neste contexto, as grandes empresas químicas e metal-mecânicas, bem como vários bancos, valeram-se do Banco de Horas como mecanismo para dissimular a maior extensão da jornada de trabalho. No caso dos bancos, a extensão da jornada sem o pagamento devido foi muitas vezes estabelecida em contratos individuais de compensação de horas extras. Outro mecanismo foi o recurso à subcontratação de empresas terceiras, cujos trabalhadores, em grande parte dos casos, recebem por hora trabalhada e não têm jornada fixa.

A terceirização tem sido normalmente associada à precarização do trabalho porque, através dela, tem se disseminado a exclusão de parte dos trabalhadores do mercado regular de trabalho, além de, na maioria das vezes, os empregados das terceiras receberem salários menores do que o piso da categoria, sem terem direito aos benefícios conquistados por ela em anos de lutas, estabelecidos nos acordos coletivos, e trabalharem sob piores condições de segurança e salubridade, sendo mais ameaçados pela instabilidade do emprego. 
O recurso à terceirização tem sido utilizado, nos três setores estudados, com o intuito primordial de reduzir custos, num contexto de acirramento da competitividade. Mas, além disso, tem também contribuído para o enfraquecimento do movimento sindical, pois muitos dos trabalhadores que são demitidos passam a trabalhar para as empresas terceiras, exercendo, freqüentemente, as mesmas funções de antes, mas deixando, em muitos casos, de pertencer à categoria.

Convém destacar o caso do setor químico, no qual se verificou, na década de 90, uma tendência de crescimento do emprego, principalmente nas pequenas empresas, ${ }^{9}$ em parte decorrente de um intenso processo de externalização de atividades, o que contribuiu para a preservação da base do sindicato da categoria, apesar da continuidade das demissões durante a década. É interessante observar, no caso deste sindicato, que apesar de o número de trabalhadores na sua base ter aumentado, as estimativas indicam a queda do índice de sindicalização entre os anos 1980 e 1997, provavelmente como reflexo da grande redução do emprego no começo dos anos 90 e do enxugamento sobretudo das grandes empresas do setor. Mas este índice volta a crescer principalmente no final da década, passando de cerca de 18\% em 1996 para cerca de 22\% em 1998 (tomando apenas os sócios ativos). ${ }^{10}$

No caso dos metalúrgicos, a expressiva redução de postos de trabalho e a intensificação do processo de terceirização nos anos 1990 levaram a uma redução da base sindical da categoria em Campinas de 27\% entre 1986 e 1997, e de 6,5\% entre 1995 e 1997, mas o nível de sindicalização apresentou uma queda proporcionalmente superior neste último período, passando de $46,4 \%$, em 1995, para 36,4\% em 1997, uma perda de 9 mil associados (Araújo e Gitahy, 1998). Isto significa que no caso dos metalúrgicos e, em menor grau, dos químicos houve uma tendência de diminuição dos índices de sindicalização, indicando uma redução do prestígio dos sindicatos junto aos seus representados.

Para o movimento sindical bancário da região de Campinas, a reestruturação também tem sido negativa, em função das novas estratégias gerenci- ais. De um lado, tem levado, nos anos 90, a uma centralização dos serviços nos principais centros financeiros do país, como São Paulo, o que acarretou, em 1995, o fechamento da Câmara de Compensação Eletrônica do Banco do Brasil em Campinas, levando à demissão de cerca de 400 bancários, ${ }^{11}$ além de resultar em transferências de funcionários para outras unidades e cidades. De outro lado, as inovações organizacionais, ao reduzirem as chefias intermediárias, bem como o número de escriturários e caixas (que são os bancários mais participantes nas atividades sindicais), levaram ao desmantelamento do plano de cargos e salários estabelecido em acordo coletivo e, juntamente com o fechamento de locais de alta concentração de trabalhadores, ${ }^{12}$ contribuíram para a diminuição da capacidade de resistência dos bancários e para o enfraquecimento da organização sindical.

No entanto, diversamente do que ocorreu nos outros dois sindicatos, entre os bancários a queda do número de sindicalizados foi proporcional à redução do emprego e o Sindicato dos Bancários conseguiu manter um alto índice de sindicalização durante a década (oscilando em torno de 65\%), apesar da enorme diminuição do número de trabalhadores na sua base.

\section{As negociações coletivas nos anos 90}

A negociação direta entre empresários e sindicatos que se generalizou no Brasil na década de 1980 constituiu instrumento privilegiado na busca dos trabalhadores por melhores salários e condições de trabalho, bem como na sua luta pela democratização das relações de trabalho. O padrão de relacionamento que se desenvolveu entre esses atores para a negociação dos contratos coletivos indicava a consolidação de um sistema articulado que combinava o estabelecimento de acordos coletivos por categoria, muitas vezes antecedidos de movimentos grevistas envolvendo o conjunto dos sindicatos representados na negociação, com conflitos e acordos por empresa através dos quais os trabalhadores procuravam ampliar os ganhos obtidos nas convenções (Silva, 1992).

As transformações políticas, econômicas e sociais que caracterizaram os anos 1990 contribuí- 
ram para enfraquecer o movimento sindical, quebrando sua unidade, e para abalar o sistema articulado de barganha coletiva que ele logrou estabelecer. As mudanças vivenciadas pelo sindicalismo brasileiro - visíveis na diminuição do ímpeto grevista e na dificuldade em mobilizar os trabalhadores - incidiram também sobre a prática da negociação coletiva. Em face da mudança na conjuntura, parte importante dos sindicatos foi levada a repensar a "estratégia do confronto", predominante na década anterior, passando a enfatizar a necessidade da negociação com o empresariado e com o Estado e de intervir, com propostas próprias, no debate das questões nacionais.

Uma das conseqüências desta mudança de prática e de estratégia, assumida pela corrente majoritária da CUT, foi o aprofundamento das divergências internas à Central e a crescente dificuldade para a manutenção da unidade entre os sindicatos a ela vinculados na condução das campanhas salariais e na negociação com o patronato.

Muitos sindicatos, fragilizados pelo crescimento do desemprego, pela perda de membros e por uma divisão marcada pelo acirramento das divergências políticas entre correntes da CUT, adotaram uma postura defensiva e não foram capazes de reagir de forma articulada a essa nova estratégia.

\section{As negociações coletivas dos metalúrgicos}

O Sindicato dos Metalúrgicos de Campinas, ${ }^{13}$ maior e mais importante sindicato da região, passou por um importante processo de renovação após a conquista de sua diretoria pela Oposição Sindical em 1984, contribuindo para a formação de um sindicalismo combativo na região (Possan, 1997). Nos anos 90, esta organização manteve um papel de destaque no cenário do sindicalismo brasileiro, seja por preservar uma importante base de apoio entre os metalúrgicos da região, apesar da expressiva redução tanto da categoria (devido à redução dos postos de trabalho) como do número de trabalhadores sindicalizados, seja por adotar, a partir da filiação de sua diretoria à corrente Fórum Socialista (antiga CUT pela Base), uma posição crítica à orientação negociadora e propositiva, hoje majoritária na CUT, e de forte oposição a certas propostas feitas pela Central, como a das Câmaras Setoriais, bem como às suas tentativas de negociar com o governo, como no caso da reforma da Previdência.

Esta postura teve repercussões importantes sobre a maneira como este sindicato veio enfrentando o conjunto de transformações associadas ao processo de reestruturação produtiva e suas implicações sobre o mundo do trabalho.

As negociações coletivas dos metalúrgicos tornaram-se mais complexas e desagregadas nos anos 90. A partir de 1993, quatro diferentes grupos de sindicatos patronais passaram a estabelecer negociações e acordos em separado com os sindicatos representados pela Federação dos Metalúrgicos da CUT: setor automotivo (montadoras e autopeças), setor de máquinas e material eletroeletrônico (Grupo 8), setor de equipamento elétrico (Grupo 10) e fundição e não-ferrosos. A partir de 1995 , no entanto, houve nova divisão, com a exclusão do Sindipeças (setor de autopeças - Grupo 5) dos acordos negociados pelas montadoras (Anfavea).

Alegando a grande heterogeneidade e diversidade de condições entre os setores e a pressão por redução de custos numa conjuntura de crise econômica, os empresários adotaram a estratégia de se dividir para negociar com os trabalhadores, $\mathrm{O}$ que impediu o estabelecimento de convenções coletivas válidas para o conjunto da categoria, criando, deste modo, dificuldades para a unificação dos metalúrgicos e para a realização de greves gerais durante as negociações anuais. ${ }^{14}$

Um primeiro exame dos acordos coletivos assinados pela categoria metalúrgica nos anos $90{ }^{15}$ permite observar que as mudanças mais importantes ocorreram nas cláusulas econômicas e principalmente naquelas diretamente relacionadas com as questões salariais. Os acordos mostram que os metalúrgicos conseguiram, até 1995, reajustes de salários que, de certa forma, garantiam a reposição da inflação do período, além de índices de aumento real variando entre $5 \%$ e $6 \%$. Além disso, uma conquista estabelecida na Convenção de 1990 e mantida nos anos seguintes, até o início do Plano Real, foi a antecipação mensal do reajuste salarial. No entanto, o estabelecimento de acordos separados dentro do setor acarretou também índices de reajuste e pisos salariais diferenciados entre os grupos. ${ }^{16}$ 
A partir de 1994, com a introdução do Plano Real e a redução dos índices de inflação, as questões salariais começaram paulatinamente a perder peso nas negociações e os reajustes mensais foram abolidos. Em 1995, os metalúrgicos conquistaram a unificação da data-base (em novembro) de toda a categoria no Estado de São Paulo. No entanto, as negociações realizadas a partir deste ano foram mais difíceis para os trabalhadores. Em 1997 não houve nenhuma mobilização durante a campanha salarial no Estado de São Paulo e os acordos assinados foram considerados os piores de toda a década. Em 1998, nenhum acordo havia sido assinado até dezembro, pois além de oferecer reajuste zero, parte das grandes empresas estava propondo redução da jornada de trabalho com redução de salários, o que foi considerado inaceitável pelos sindicatos cutistas envolvidos na negociação.

Quanto às chamadas cláusulas sociais, ${ }^{17}$ cabe salientar que elas foram incluídas nos acordos ao longo dos anos 80 e não sofreram, nos anos 90, nenhuma modificação significativa, nem foram acrescidas de novos benefícios. Isto significa que, em vez da conquista de melhorias nas condições e relações de trabalho, o que se verificou nos anos 90 foi o esforço dos sindicatos metalúrgicos para manter o que já tinha sido conquistado diante das tentativas constantes do patronato de reduzir essas conquistas. Nas negociações de 1997, os sindicatos patronais do ramo metalúrgico, com exceção daqueles das montadoras e autopeças, insistiram e conseguiram a retirada de algumas destas cláusulas. Mas foi no ano de 1998, em meio à crise que atingiu o país em decorrência da especulação financeira e desvalorização da moeda, que os trabalhadores sofreram as maiores perdas, com a retirada de 40 cláusulas sociais, dentre as quais direitos importantes como a estabilidade do trabalhador acidentado ou portador de doença profissional.

Chama a atenção, além das perdas que os trabalhadores vêm sofrendo, o fato de que as intensas transformações ocorridas no interior das empresas com a introdução das inovações tecnológicas e de novas formas de gestão do trabalho não se refletiram nas negociações coletivas da categoria metalúrgica. Ao longo de toda a década nenhu- ma cláusula relativa às novas questões colocadas pelo processo de reestruturação foi incorporada aos acordos com validade para toda a categoria.

A diminuição da importância da barganha coletiva centralizada e o crescimento substancial das negociações realizadas no âmbito das empresas já foram apontados por alguns autores como sendo a tendência predominante no plano internacional (Baglioni, 1994). No Brasil, esta tendência também passou a ser predominante nos anos 1990. Estudos recentes (Bresciani, 1994; Gitahy e Bresciani, 1997) têm mostrado que a negociação das condições de implantação e desenvolvimento dos novos processos associados à reestruturação produtiva tem avançado principalmente na indústria automobilística do ABC paulista, onde o sindicato tem forte presença no interior das empresas através de comissões de fábrica organizadas desde os anos 80. As comissões de fábrica têm desempenhado um papel essencial na negociação de questões como terceirização, programa de melhorias contínuas, células de produção e trabalho em equipe, sistema de apoio logístico, redução da jornada com tempo flexível e participação nos resultados. No entanto, este tipo de negociação coletiva permanece restrita ao ABC, pois, como observa Bresciani (1994, p. 205), "o volume da ação sindical em face da questão tecnológica/organizacional é extremamente reduzido, se considerarmos o conjunto da indústria brasileira. No que diz respeito à negociação, ainda que uma série de pautas sindicais possa abordar o tema, acordos efetivos (mesmo que tácitos) são ainda exceções."

No Sindicato dos Metalúrgicos de Campinas, a tendência às negociações por empresa pode ser observada desde os anos 80. No entanto, a maioria dos temas negociados é ainda relativa à questão salarial (reajuste, reposição de perdas, aumento real, piso salarial) e às condições de trabalho (refeitório, convênio médico, condições de trabalho insalubres e perigosas, renovação de benefícios sociais). Um outro conjunto de temas, no entanto, refere-se às conseqüências do processo de reestruturação produtiva, e aqui é a questão da manutenção do emprego que aparece com mais freqüência (estabilidade temporária no emprego, suspensão de demissões, reintegração e garantias 
aos demitidos). A questão da indenização a portadores de LER foi negociada somente em 1997 e em apenas quatro empresas.

Os temas mais diretamente relacionados com as transformações no processo de trabalho negociados por este sindicato foram: plano de cargos e salários, horário flexível e participação nos lucros e resultados (PLR). Mas os próprios dirigentes sindicais reconhecem que muitas empresas estabelecem o pagamento da PLR sem consultar o sindicato e o condicionam ao alcance de metas de produção, à redução de absenteísmo etc.

A inexistência de formas de representação dos trabalhadores no interior das empresas, o fato de o sindicato atuar na porta de fábrica e ter dificuldade de se fazer presente em uma parte importante das empresas de sua base, certamente constitui um grande empecilho para que os trabalhadores organizados possam exercer influência sobre o processo de reestruturação e avançar nas negociações das questões a ele relacionadas. No entanto, as dificuldades encontradas pelo Sindicato dos Metalúrgicos de Campinas em concretizar esta influência estão não só relacionadas à dificuldade de mobilização dos trabalhadores em face do medo do desemprego, mas também à intransigência patronal em aceitar o sindicato como interlocutor na discussão das questões relativas ao processo de reestruturação e, provavelmente, à orientação política assumida pelos sindicalistas de confronto com o patronato e recusa da postura negociadora hoje predominante nos sindicatos da CUT. A estes fatores soma-se, ainda, a dificuldade destes sindicalistas em compreender o que estava ocorrendo nas fábricas e sua postura diante do processo de reestruturação. Nas palavras de um dos diretores por nós entrevistados:

Eu diria que nós estamos numa posição que oscila da omissão à crítica. Omissão por ignorância, porque o sindicato não enxergou este fenômeno antes e pegou atrasado o bonde. Em geral de crítica [...] porque, você sabe, esta reestruturação tem uma carga ideológica grande [...] Eles convocam o trabalhador para vestir a camisa, para ser parte integrante da empresa [...] então eles criam este ambiente de convencimento, de ganhar a cabeça do cara [...] o sindicato enfrenta isto criticando, questionando. ${ }^{18}$

Este depoimento mostra que a estratégia do sindicato tem sido privilegiar a crítica à postura ideológica envolvida na reestruturação e o combate aos seus efeitos mais perversos. Sua atuação no enfrentamento destas questões tem se pautado, predominantemente, pela resistência a determinados expedientes como a terceirização, a flexibilização da jornada de trabalho, o fechamento de postos de trabalho, e pela defesa dos trabalhadores contra a redução e/ou flexibilização de seus direitos.

Este tipo de atuação tem sido importante na tentativa de reduzir os impactos negativos das transformações produtivas sobre os trabalhadores, mas tem se mostrado restrita e pouco eficaz no que diz respeito à luta sindical pela democratização das relações de trabalho no espaço fabril. A contraposição entre a "estratégia do confronto" e a "estratégia propositiva” tem também criado entraves para que o sindicato se capacite a apresentar reivindicações e propostas concretas voltadas para uma participação efetiva dos trabalhadores nas decisões relativas à introdução de novas tecnologias e de programas de gestão da força de trabalho.

\section{As negociações coletivas dos químicos}

Diferentemente dos outros sindicatos analisados, a oposição assumiu a direção do Sindicato dos Químicos de Campinas somente em 1992. Além de se deparar com uma categoria sem tradição de luta e acomodada a uma prática sindical assistencialista, a nova direção teve de enfrentar os efeitos perversos do processo de reestruturação nas empresas da região, o que afetou seu poder de barganha nas negociações.

Mesmo com a postura mais combativa adota$\mathrm{da}$, a nova diretoria enfrentou dificuldades para mobilizar a categoria, deflagrar greves e estar mais próxima do chão-de-fábrica, acompanhando as mudanças tecnológicas e organizacionais. Além do fantasma do desemprego, o sindicato teve de lutar contra o avanço da terceirização (que fragmenta a base ao levar para dentro da fábrica trabalhadores de categorias diferenciadas e filiadas a outros sindicatos) e enfrentar os chamados "programas 
participativos", através dos quais as gerências concorrem com o sindicato na busca da adesão dos trabalhadores às metas da empresa. ${ }^{19}$

Tais fatores geraram uma crescente insegurança entre os trabalhadores, o que se refletiu na diminuição das taxas de sindicalização e das greves, ${ }^{20}$ e alteraram a dinâmica da negociação nos anos 90. Fragilizado, o sindicato passou a ver como cada vez mais distante a possibilidade de incorporação de novas cláusulas. Mas, diferentemente do setor metalúrgico, que se dividiu em subgrupos nas negociações anuais da categoria, os sindicatos químicos conquistaram alguns benefícios por terem mantido suas negociações unificadas em âmbito estadual através do grupo Ceag-10 da FIESP, uma prática que vem desde os anos 1980. Ademais, os sindicatos químicos vinculados à CUT passaram a ser representados nas negociações pela Confederação Nacional dos Químicos (CNQ), com campanhas salariais unificadas a partir de 1992.

O exame desse processo mostra que, nos primeiros anos da década de 1990, as medidas adotadas pelo governo Collor afetaram a indústria química, levando os sindicatos a privilegiarem, nas negociações, a questão salarial, reivindicando reposição de perdas, aumento real, reajustes mensais, e a questão das demissões motivadas pela introdução de novas tecnologias.

Analisando o conjunto das cláusulas econômicas, é possível perceber que, pelo menos até 1993, os químicos conseguiram reajustes salariais que repunham integralmente a inflação a cada ano, embora não tenha sido possível negociar as perdas acumuladas nos sucessivos planos econômicos. A categoria tampouco conseguiu vencer a resistência patronal à reivindicação de reajustes mensais. Apesar disso, antecipações (geralmente semestrais) foram concedidas por empresas do setor, o que, entretanto, nunca foi estabelecido em acordos ou termos aditivos da categoria, ao contrário do que ocorreu com os metalúrgicos, que conseguiram negociar este item na Câmara Setorial.

A partir da vigência do Plano Real, os reajustes alcançados não conseguiram recompor o poder de compra dos salários. A comparação entre os reajustes salariais obtidos pelos metalúrgicos e pelos químicos (Tabela 7) a partir de 1994 permite perceber que estes últimos obtiveram índices ligeiramente inferiores aos obtidos por aqueles. Em 1994 os químicos receberam um reajuste equivalente ao do Grupo 5 (autopeças), com a vantagem do acréscimo de um abono, mas inferior aos concedidos pelas montadoras e pelos setores de fundição e de máquinas (Grupo 8). A diferença mais importante verificou-se em 1995, quando, além de um reajuste maior, os diferentes setores da indústria metalúrgica concederam 6\% de aumento real a título de produtividade.

De maneira sistemática ao longo desta década, os sindicalistas da categoria química lutaram para melhorar estes índices de reajuste mediante negociações por empresa. Em Campinas, foram bem-sucedidos em alguns anos, principalmente nas grandes empresas do pólo.

Tabela 7

Índices de Reajuste Salarial Obtidos nas Negociações Coletivas dos Metalúrgicos, Químicos e Bancários do Estado de São Paulo, 1994-1997

\begin{tabular}{|c|c|c|c|c|}
\hline & \multicolumn{4}{|c|}{ Indices de reajuste } \\
\hline Categorias & 1994 & 1995 & 1996 & 1997 \\
\hline $\begin{array}{l}\text { Metalúrgicos } \\
(\mathrm{Gr}-5)^{*}\end{array}$ & $\begin{array}{c}15,6 \% \\
(10 \% \text { em } \\
\text { dez. 1994, } \\
3,6 \% \text { em } \\
\text { jan. } 1995 \\
\text { e } 1,5 \% \text { em } \\
\text { fev. } 1995)\end{array}$ & $\begin{array}{c}35,3 \% \\
(15,3 \% \text { em } \\
\text { abr. } 1995 \mathrm{e} \\
14,07 \%+ \\
6 \% \text { produ- } \\
\text { tividade em } \\
\text { nov. 1995) }\end{array}$ & $8 \%$ & $4 \%$ \\
\hline Químicos & $\begin{array}{c}15,6 \%+ \\
\text { abono de } \\
\mathrm{R} \$ 100,00\end{array}$ & $25 \%$ & $8 \%$ & $3,7 \%$ \\
\hline $\begin{array}{l}\text { Bancários } \\
\text { (Fenaban) }\end{array}$ & $16 \%$ & $30 \%$ & $\begin{array}{c}10,8 \%+ \\
\text { abono de } \\
45 \% \text { de } \\
\text { salário }\end{array}$ & $5 \%$ \\
\hline
\end{tabular}

*O Grupo 5 (autopeças) foi tomado como parâmetro, pois os reajustes por ele concedidos aproximavam-se da média dos diferentes reajustes obtidos nos demais grupos da indústria metalúrgica.

Fonte: Convenções coletivas e termos aditivos assinados pelos Sindicatos dos Metalúrgicos e dos Químicos do Estado de São Paulo e pelos sindicatos dos bancários em âmbito nacional.

Os pisos salariais dos químicos também foram reajustados anualmente de acordo com o reajuste salarial e acompanharam de perto os pisos recebidos pelos metalúrgicos, tendo sido superior aos destes em 1991, 1992 e 1996 (Tabela 8). A partir 
de 1994, com a eliminação do piso de admissão, os químicos tiveram um ganho em relação aos metalúrgicos por terem unificado o piso para toda a categoria, no momento em que aqueles ampliavam a diferenciação dos pisos nas pequenas, médias e grandes empresas.

A partir do Plano Real, portanto, as negociações tornaram-se cada vez mais difíceis, marcadas por conquistas menos expressivas. A crescente dificuldade em alcançar reajustes integrais de salário fez com que o Sindicato de Campinas passasse a insistir em outras questões, como o pagamento da PLR. Os dirigentes sindicais consideram que a negociação da PLR abre a possibilidade de ampliar sua representação junto aos trabalhadores, de obter informações mais precisas sobre as empresas, além de ser uma das poucas oportunidades de influenciar na reestruturação produtiva. Sua luta tem sido para que a proposta patronal de pagamento da PLR não implique o estabelecimento de metas de produção ou de condições relativas a absenteísmo.

No que se refere às cláusulas sociais, é possível perceber que os sindicatos dos químicos, diferentemente dos sindicatos dos metalúrgicos, tive- ram alguns ganhos com a inclusão de novas cláusulas nas convenções coletivas, mas que também se concentraram nos primeiros anos da década, quando foram organizadas algumas greves mais amplas.

Foram incorporadas cláusulas importantes relativas ao combate de alguns dos impactos negativos da reestruturação produtiva, principalmente relativas à saúde do trabalhador, como a prevenção de acidentes com equipamentos, a instalação de mecanismos de proteção nas máquinas e a exigência de treinamento na introdução de novas técnicas de produção. Foram também negociadas cláusulas limitando o emprego de mão-de-obra temporária e estendendo a estes trabalhadores as medidas de proteção, além de uma cláusula relativa à garantia de "salário igual para trabalho igual", considerada pelos sindicalistas como uma importante contrapartida à polivalência. Além disto, obteve-se o aumento dos índices do pagamento das horas extras e do adicional noturno, a ampliação da licença-maternidade para mães adotantes e a garantia de emprego em caso de aborto legal.

Embora estes ganhos possam ser justificados pelo maior índice de produtividade do setor no

Tabela 8

Pisos Salariais Estabelecidos nas Convenções dos Metalúrgicos, Químicos e Bancários (1990-1997)

\begin{tabular}{|c|c|c|c|c|c|c|c|c|c|}
\hline Categoria & & $1990^{(\mathrm{b})}(\mathrm{Cr} \$)$ & $1991^{(\mathrm{b})}(\mathrm{Cr} \$)$ & $1992^{(\mathrm{c})}(\mathrm{Cr} \$)$ & $1993^{(\mathrm{d})}(\mathrm{Cr} \$)$ & $1994^{(\mathrm{e})}(\mathrm{R} \$)$ & $1995(\mathrm{R} \$)$ & $1996(\mathrm{R} \$)$ & $1997(\mathrm{R} \$)$ \\
\hline \multirow[t]{2}{*}{ Metalúrgicos } & $\begin{array}{l}\text { Até } 700 \\
\text { empregados }\end{array}$ & $20.000,00$ & $79.780,00$ & $1.133 .372,00$ & $46.000,00$ & 178,00 (fev.) & $260,00^{(\mathrm{f})}$ & 260,00 & 293,00 \\
\hline & $\begin{array}{l}\text { Mais de } 700 \\
\text { empregados }\end{array}$ & $25.000,00$ & $103.714,00$ & $1.391 .310,00$ & $56.000,00$ & 220,84 & 296,00 & 296,00 & 333,00 \\
\hline \multirow[t]{2}{*}{$\overline{\text { Químicos }}^{(\mathrm{a})}$} & Admissão & $19.208,00$ & $122.012,00$ & $1.700 .000,00$ & $39.900,00$ & 215,00 & 285,00 & 308,00 & 320,00 \\
\hline & Efetivação & $21.215,00$ & $131.213,00$ & $1.850 .000,00$ & $43.410,00$ & - & - & - & - \\
\hline \multirow{2}{*}{$\begin{array}{l}\text { Bancários } \\
\text { (Fenaban) }\end{array}$} & Admissão & $28.000,00$ & $126.405,00$ & $1.566 .000,00$ & $32.000,00$ & 274,13 & 373,00 & 418,00 & 438,90 \\
\hline & Efetivação & - & - & - & $35.200,00$ & 301,54 & 410,00 & 460,00 & 483,00 \\
\hline
\end{tabular}

(a) Os químicos têm sua data-base no mês de novembro de cada ano.

(b) Nestes dois anos, baseamo-nos no termo aditivo assinado pelos sindicatos dos metalúrgicos no mês de novembro, atualizando os valores acordados na convenção coletiva da categoria assinada em abril.

(c) Neste ano, tomamos como parâmetro para os metalúrgicos o termo aditivo assinado em novembro pelo Grupo 8.

(d) Em 1993, os dados para os metalúrgicos são da convenção coletiva assinada em novembro pelas montadoras, Grupos 5 e 8. (e) De 1994 em diante tomamos como base as convenções assinadas pelos Grupos 5 e 8. Apenas para 1994 os dados são relativos a fevereiro. A partir deste ano os químicos eliminaram o piso de admissão.

(f) A partir de 1995 as convenções dos metalúrgicos passaram a estabelecer três pisos diferenciados: para empresas de até 50 funcionários, de 51 a 500 e com mais de 500 funcionários. Para esta comparação estamos considerando apenas os dois últimos.

Fontes: Convenções coletivas e termos aditivos assinados pelos sindicatos dos metalúrgicos e dos químicos do Estado de São Paulo e convenções coletivas assinadas pelo conjunto dos sindicatos dos bancários, em nível nacional (representando todos os trabalhadores dos bancos privados), e pela Federação Nacional dos Bancos (Fenaban). 
período, é também importante observar que estas conquistas decorreram muito mais da resistência dos sindicatos durante as negociações. Apesar da fragilidade do Sindicato de Campinas, as novas conquistas refletiram a força dos grandes sindicatos da categoria (ABC e São Paulo), que conseguiram manter, nesta década, uma certa capacidade de pressão e garantir, através das negociações unificadas, melhorias para todos os químicos no âmbito do Estado de São Paulo.

A partir de 1995, diante de um cenário macroeconômico desfavorável à organização sindical, as negociações realizaram-se sem grandes mobilizações dos trabalhadores, dificultando a conquista de novos direitos e benefícios. As reivindicações voltaram-se para a reposição das perdas com a mudança da moeda, o acesso dos trabalhadores à informação sobre a produção e a introdução de novas tecnologias, a organização em locais de trabalho, a eleição de delegados sindicais e o combate à terceirização.

Com negociações cada vez mais difíceis, marcadas por impasses devido à insistência patronal na eliminação de diversos benefícios, o Sindicato dos Químicos de Campinas procurou negociar por empresa. Assim, como foi observado para os metalúrgicos, também entre os químicos as negociações por empresa assumiram um papel importante nos anos 1990, tanto como mecanismo de encaminhamento de reivindicações específicas e solução de conflitos internos a cada empresa, quanto como forma de melhoria das cláusulas acordadas nas negociações gerais da categoria.

Acompanhando os boletins do Sindicato de Campinas, é possível perceber que tal estratégia foi intensificada a partir de meados da década, e que os principais temas discutidos foram: aumento de salário, questões relativas ao ambiente de trabalho e implantação do quinto turno ininterrupto. O ano de 1996 foi um ano significativo para as negociações por empresa. O sindicato conseguiu mobilizar os trabalhadores a partir de pautas que incluíam questões específicas das empresas, organizando várias assembléias e paralisações localizadas que tiveram como resultado o fechamento de vários acordos. ${ }^{21}$

Embora questões relativas ao processo de reestruturação constassem tanto das pautas unifi- cadas entregues à FIESP quanto das pautas específicas enviadas às empresas, elas não chegaram a ser objeto das negociações do período, devido à resistência patronal. Da mesma forma, os delegados sindicais e as comissões de fábrica estiveram ausentes dos acordos assinados, contribuindo para distanciar ainda mais o sindicato da base e dificultando o acompanhamento das transformações em curso no âmbito fabril e a elaboração de estratégias de resistência.

Isto evidencia o enfraquecimento dos sindicatos químicos em geral e do de Campinas em especial, sua dificuldade em se fazerem presentes nas empresas e em negociar, como representantes dos interesses dos trabalhadores, as condições de introdução de mudanças tecnológicas e organizacionais.

As negociações coletivas dos bancários nos anos 90 O sindicalismo bancário apresenta uma forte tradição de luta no Brasil. Neste movimento, o Sindicato de Campinas possui uma presença destacada desde 1983, quando sua direção passou às mãos de um grupo de oposição. Durante a década de 1980, este sindicato consolidou uma atuação mais propositiva, defendendo a negociação permanente com os bancos como a melhor forma de obter direitos e benefícios para a base.

O movimento sindical bancário fortaleceu-se ao longo dos anos 80 apoiado sobretudo pelos bancos públicos, onde a mobilização era maior, o que repercutiu na conquista de uma série de benefícios para a categoria. O maior destaque do movimento na década foi a greve nacional de 1985 , que conseguiu paralisar por três dias todo o sistema bancário brasileiro. Desde este ano, as negociações coletivas dos bancários passaram a ser realizadas de forma unificada em âmbito nacional, uma singularidade no país, embora os bancos públicos assinem acordos separadamente dos privados.

Nos primeiros anos da década de 1990, predominava um cenário que se assemelhava ao dos anos 1980. Em função da corrosão salarial promovida pela inflação, predominavam entre os bancários, como nas outras categorias, as reivindicações econômicas. As altas taxas inflacionárias contribuíam para a alta rentabilidade dos bancos que, pressiona- 
dos pela mobilização da categoria, apresentaram uma postura mais receptiva à negociação.

Em 1990 e 1991, durante o governo de Fernando Collor, ocorreu a primeira grande onda de demissões no setor, especialmente nos bancos públicos federais. O crescente descontentamento dos bancários levou à realização de greves tanto na rede pública quanto na privada, o que contribuiu para a melhoria dos reajustes salariais. Mas iniciouse também, neste período, a ofensiva dos dirigentes dos bancos públicos federais, que retiraram as garantias concedidas aos dirigentes sindicais, no intuito de enfraquecer o movimento dos trabalhadores.

Nos anos 1990, diferentemente da década anterior, foram os bancos privados que passaram a comandar as negociações dos bancários. A situação econômica mais favorável à rentabilidade destes bancos foi um dos motivos que propiciou a concordância da Fenaban com reajustes maiores que os previstos na legislação salarial, pelo menos até 1995 , quando passou a prevalecer, por iniciativa do governo, a livre negociação. Quanto aos bancos públicos, a Nossa Caixa e o Banespa acompanharam a Fenaban. Já os bancos federais (Banco do Brasil e Caixa Econômica Federal), que vinham passando por intensa reforma administrativa com a finalidade de se adequarem ao contexto de maior competitividade, não concederam, durante toda a década, nenhum reajuste que superasse a legislação salarial. ${ }^{22}$

A partir de 1995, o impacto do fim das transferências inflacionárias sobre a rentabilidade dos bancos refletiu-se sobre as negociações coletivas dos bancários, que passaram a ser muito mais longas, sem que seus resultados significassem grandes avanços. Foram freqüentes os ajuizamentos de dissídios coletivos, principalmente por parte dos bancos públicos federais.

Do ponto de vista econômico, conforme a estabilidade foi se tornando uma realidade mais duradoura, as campanhas voltaram-se para outras reivindicações, como aumento dos pisos, produtividade e PLR. No caso dos bancos privados, o resultado das negociações foi positivo em termos econômicos para os bancários nesta segunda metade da década. ${ }^{23}$ Já os públicos federais apresenta- ram-se ainda mais intransigentes nas negociações. Além das perdas já acumuladas na primeira metade da década, os funcionários destes bancos não receberam reajustes salariais depois de 1995, mas apenas abonos.

Assim, durante o governo de Fernando Henrique Cardoso, da mesma forma que os bancos tiveram de se adaptar rapidamente a uma série de medidas que aceleraram a reestruturação financeira, também o movimento sindical sentiu a necessidade de reformular suas estratégias de atuação, de modo a enfrentar o contexto de flexibilização e de desregulamentação do trabalho. Em 1994 e 1995 foram realizadas pequenas paralisações nos bancos, mas isto não resultou em melhorias nas negociações. Em 1995, a situação mostrava-se bastante desfavorável aos bancários, em função da crise no México e conseqüiente fragilização de todo o sistema financeiro brasileiro, tendo ocorrido uma explosão nas demissões. O Banco do Brasil vinha apresentando prejuízos desde 1994 e, na segunda metade de 1995, já havia lançado o primeiro Programa de Demissões Voluntárias (PDV), deixando seus funcionários ainda mais apreensivos.

Desde 1996 a rentabilidade dos bancos voltou a crescer bastante, mas nem por isso as negociações melhoraram e cessaram de crescer as pressões para a eliminação de vários benefícios da categoria, dentre eles o anuênio, uma conquista de mais de 50 anos. Ainda neste ano, o Sindicato dos Bancários de Campinas tomou iniciativas no sentido de reverter esse quadro, como a realização de uma "greve pipoca" que atingiu 12 bancos. Em 1997 foi lançada a "Caravana Agita Bancário", que percorreu o Estado de São Paulo promovendo paralisações nas agências de várias cidades. A manifestação incluiu a paralisação da matriz central do Bradesco, em Osasco, com a presença de sete mil bancários e de mil dirigentes sindicais. Neste mesmo ano, também a sede central do Banco do Brasil, em Brasília, foi paralisada, com a presença de quatro mil funcionários.

Apesar desta mobilização, as negociações continuaram difíceis. Embora tenha sido mantido o anuênio e obtidas algumas outras pequenas conquistas, elas foram mais fruto da resistência do movimento sindical durante as negociações do 
que da elaboração de uma estratégia efetiva que lhe permitisse recuperar o poder de barganha da década anterior. Como disse o presidente do Sindicato de Campinas: "Não há mais a ilusão quanto ao que se possa obter pelas mobilizações." ${ }^{24}$ Este quadro de fragilidade do movimento sindical tem fortalecido os bancos em seu intuito de retirar direitos e benefícios dos bancários, que, diante das pressões que vêm sofrendo pelas transformações no mercado de trabalho, têm se contentado com a preservação de qualquer forma de emprego.

Nos primeiros anos da década, a mobilização da categoria concorreu para a melhoria das propostas dos bancos não somente quanto aos reajustes salariais, como também em relação à ampliação de benefícios conquistados na década anterior, como auxílios e proteção à saúde do trabalhador. Chama a atenção, nos acordos do Banespa, a inclusão de cláusulas referentes ao pagamento do tratamento de doenças ocupacionais, o aumento da estabilidade provisória na volta ao trabalho após afastamento por licença-saúde e a implantação de uma política de prevenção às LER e de readaptação profissional dos lesionados.

Na segunda metade da década, entretanto, diante das pressões dos bancos, sobretudo nos públicos, o movimento sindical não conseguiu impedir a perda de alguns benefícios (como a isenção de tarifas, o adicional de transferência, a proteção nos casos de fechamento de unidades, a licença-prêmio, o auxílio-educação para novas admissões etc.), ainda que esta perda não tenha sido tão significativa quanto a verificada nas últimas negociações dos metalúrgicos e químicos.

As questões relativas aos impactos da reestruturação financeira começaram a ser fortemente reivindicadas pelo movimento sindical bancário principalmente a partir de 1993, mas estiveram restritas, de um modo geral, aos problemas do fechamento de postos de trabalho, da participação nos lucros e resultados (PLR), da terceirização e da saúde, que foi afetada pela intensificação do trabalho e pelo uso mais freqüente de computadores. A partir de 1994, mas sobretudo nos anos posteriores, quando a questão salarial teve sua importância diminuída, foram estes os principais pontos tratados nas campanhas salariais.
Assim, a luta contra as demissões foi a principal bandeira do sindicalismo bancário nesta década. Mas, apesar de ter conseguido estabelecer cláusulas obrigando os bancos a pagarem multas caso ocorressem demissões sem justa causa, tal medida não conseguiu evitar o crescimento do desemprego no setor, ${ }^{25}$ possivelmente pelo baixo custo das demissões sem justa causa no Brasil.

A questão da saúde apareceu com freqüência nas negociações coletivas dos bancários, sobretudo o problema das LER, doença que cresceu enormemente na década de 1990 e que está diretamente relacionada com o processo de automação e com a intensificação do trabalho no setor. Dentre os resultados positivos destas negociações estão cláusulas como a constituição de uma comissão de saúde, o pagamento de cesta-alimentação aos afastados por LER e o aumento do tempo de pagamento da complementação de auxílio-doença, nos acordos da Fenaban; ou o direito dos lesionados ao recebimento de remuneração por prazo indeterminado e ao pagamento do tratamento da doença, além do aumento da estabilidade após o seu retorno ao trabalho, na CEF. ${ }^{26}$ Todas estas conquistas, entretanto, são paliativos que não irão resolver o problema do crescimento acelerado dos casos de LER entre os bancários, já que não interferem nas condições de trabalho que provocam a doença.

Da mesma forma, não surgiram cláusulas que tratassem da questão da terceirização, tanto nos acordos dos bancos públicos quanto nos dos privados. Exceto a criação de uma comissão paritária para discutir o assunto, instaurada desde 1995, não houve qualquer medida que visasse à interrupção deste processo que tem significado a expansão da desregulamentação e da precarização do emprego. De um modo geral, a luta do sindicato tem sido pela incorporação dos trabalhadores das empresas subcontratadas à categoria bancária.

Por outro lado, destaca-se nas negociações coletivas dos bancários, desde 1995, a presença da cláusula sobre PLR. Esta negociação é importante porque a PLR está diretamente relacionada à introdução dos programas de metas e de avaliação de desempenho. No entanto, a forma como a cláusula da PLR aparece nos acordos dos bancários de- 
monstra que o seu pagamento tem significado uma forma de aumentar os ganhos econômicos dos bancários, quando a discussão sobre reajuste salarial tornou-se quase obsoleta. As decisões sobre PLR têm sido tomadas de forma unilateral pelos bancos. Em geral, representam a concessão de abonos e não de uma porcentagem dos lucros, como reivindicam os sindicatos, pois para isto os bancos teriam de abrir as informações sobre a sua situação financeira, questão que eles se recusam, de forma peremptória, a negociar. ${ }^{27}$

É possível concluir que, ao longo dos anos 1990, as conseqüências da reestruturação financeira sobre o trabalho bancário, que se mostraram, acentuadamente, na diminuição significativa dos postos de trabalho e na mudança do perfil da categoria, refletiram-se perversamente sobre a capacidade de mobilização do sindicato. Além disso, a velocidade com que as transformações ocorreram durante a década atropelou as possibilidades de o movimento sindical acompanhar e compreender as mudanças, dificultando a execução de estratégias de resistência e retardando a formulação de contrapropostas.

Com isso, apesar de o Sindicato dos Bancários de Campinas adotar uma postura favorável às negociações, os resultados da barganha coletiva têm sido desfavoráveis aos bancários, em conseqüência da assimetria de forças das partes envolvidas. Esta assimetria tende a se aprofundar em um contexto de transformações profundas e aceleradas, devido tanto às tentativas de flexibilização da legislação trabalhista e sindical e de privatização dos bancos públicos, quanto ao fato de os sindicatos não conhecerem e não controlarem a totalidade do processo de reestruturação.

Entretanto, se enfatizamos as dificuldades da atuação do sindicalismo bancário no contexto dos anos 1990, não devemos nos esquecer de que a ela contrapomos, como parâmetro, a atuação verificada na década de 1980, que foi extremamente positiva para o movimento sindical brasileiro, com enorme expansão das negociações, do poder de barganha dos sindicatos e, em conseqüência, dos acordos coletivos, enriquecidos com uma série de novas cláusulas, direitos e benefícios. Por isso, analisando com mais cautela os resultados das negociações da categoria bancária na última década, e comparando-os com os das outras categorias aqui estudadas, podemos perceber que, apesar de os bancos terem se posicionado gradativamente de maneira mais intransigente nas negociações, pressionando para a eliminação de algumas conquistas dos bancários, estes conseguiram manter a maioria delas, além de ampliar algumas, principalmente as cláusulas sociais, o que não aconteceu nos outros setores aqui considerados. Além disso, do ponto de vista salarial, os bancários foram a categoria que menos perdeu com a corrosão inflacionária dos primeiros anos da década e que também no período pós-estabilização econômica obteve reajustes salariais razoáveis, diferentemente do que ocorreu com a maioria dos trabalhadores do país, excetuando-se, é claro, o caso dos funcionários dos bancos públicos federais, que constituiu uma exceção importante na década de 1990, em função da intensa reestruturação administrativa por que passaram estes bancos, visando à sua efetiva e completa inclusão em um mercado mais competitivo e à sua provável privatização.

\section{Considerações finais}

Nos anos 1990, a crise econômica e a aceleração do processo de modernização das empresas e bancos, com suas conseqüências perversas sobre o mercado de trabalho, fragilizaram os sindicatos, minando seu poder de barganha e levando-os a assumir uma posição defensiva no plano das negociações coletivas. A abertura da economia, o avanço das políticas neoliberais, a flexibilização dos contratos de trabalho, a intensificação do processo de terceirização e o aumento do desemprego contribuíram para ampliar a fragmentação do mercado de trabalho e acirrar a concorrência entre os trabalhadores, reduzindo a sua capacidade de mobilização. Como conseqüência, é possível observar a redução do número de greves e a queda nos índices de sindicalização. Adotando uma posição cada vez mais defensiva, os sindicatos tiveram de lutar para ao menos preservar os direitos e benefícios conquistados nos anos 80 .

Nos três setores estudados, observamos que o processo de reestruturação das fábricas e bancos 
caracterizou-se pela combinação de inovações tecnológicas com novas formas de gestão que, conjuntamente, tiveram impacto decisivo sobre o perfil dos trabalhadores "sobreviventes", sobre a atuação dos sindicatos e sobre as negociações coletivas destas categorias no decorrer dos anos 90. Queremos ressaltar que a utilização de computadores e de equipamentos de base microeletrônica, ou seja, o recurso às novas tecnologias, teve um impacto negativo importante sobre o nível de emprego, devido à sua natureza poupadora de mão-de-obra. Entretanto, quando tais equipamentos são combinados com a introdução de novos métodos de gestão da produção, os resultados sobre a redução do emprego e sobre a alteração do conjunto das relações de emprego são muito mais significativos.

Nos setores metalúrgico, químico e bancário, em que pesem suas diferenças, observamos que a utilização de programas participativos foi acompanhada de uma redução das chefias intermediárias e de uma agregação de funções aos cargos, o que tornou os trabalhadores multifuncionais e levou à maior intensificação do ritmo de trabalho, resultando tanto no aumento das demissões quanto no envolvimento e maior dedicação dos trabalhadores.

Observamos uma grande ampliação das experiências com o trabalho em grupo, que acompanharam a introdução de programas participativos, principalmente nas indústrias químicas e metalmecânicas, como uma forma de as empresas buscarem um maior comprometimento dos trabalhadores e o aumento da produtividade. O maior envolvimento com a qualidade e a maior responsabilidade dos trabalhadores no chão-de-fábrica e nos bancos levaram a um crescimento da competição entre eles (pois o trabalho em equipe visa ao comprometimento com a empresa, e não à solidariedade entre os trabalhadores), com reflexos perversos sobre a representatividade e a capacidade de mobilização dos sindicatos, que se viram competindo com as gerências pela adesão dos trabalhadores.

A redução do poder de barganha dos sindicatos deveu-se também, em grande medida, à intensificação do processo de terceirização, que segmenta os trabalhadores e exclui parte significativa dos trabalhadores terceirizados das categorias profissionais a que deveriam pertencer em função das atividades que exercem e, portanto, do direito de serem representados nas negociações pelos sindicatos destas categorias.

Temos de considerar, enfim, o impacto decisivo do temor do desemprego sobre a capacidade de mobilização dos trabalhadores, que adotam uma postura mais defensiva e deixam de responder aos apelos e estímulos dos sindicatos, preferindo, a tudo, a preservação do seu emprego. Isto contribui, também, para que acordos pouco vantajosos sejam aceitos com maior facilidade pelos trabalhadores, o que acaba incentivando o patronato em suas investidas pela redução de benefícios e a desregulamentação e precarização das relações de emprego. Assim, se observamos, por um lado, que o processo de reestruturação contribuiu para a modificação do perfil das três categorias, que se tornaram mais estáveis, mais escolarizadas e com uma maior presença feminina, também observamos, por outro lado, além do crescimento do desemprego, a deterioração das condições de trabalho (especificamente pelo crescimento alarmante dos casos de LER) e de vida daqueles que continuam empregados.

Ao longo dos anos 90, pudemos verificar que os resultados das negociações coletivas foram sendo gradativamente piores para os trabalhadores, mas principalmente para os metalúrgicos e químicos. Nos acordos destas categorias, realizados desde o início da década, os reajustes salariais concedidos foram menores do que os obtidos pelos bancários (com exceção dos bancos públicos federais, sobretudo no final da década), que, além disso, tiveram mais êxito nas cláusulas referentes aos benefícios sociais. Esta diferença de poder de barganha entre os sindicatos destas categorias deve-se, em grande medida, à peculiaridade da forma como são realizadas as negociações dos bancários.

Comparando as três categorias quanto à forma como são organizadas suas negociações coletivas, constatamos que, enquanto os metalúrgicos foram segmentados em subgrupos para realizar as negociações anuais com distintos sindicatos patronais, o complexo químico do Estado de São Paulo, 
apesar de sua grande heterogeneidade interna, manteve ao longo dos anos 90 negociações unificadas com o conjunto dos sindicatos de trabalhadores desta categoria. De forma semelhante, a categoria bancária também realizou suas negociações de forma unificada nacionalmente, embora separada entre os bancos públicos e privados.

No caso dos químicos, a manutenção de negociações unificadas significa que se para os empresários de um ramo tão heterogêneo a representação unificada perante os trabalhadores nem sempre é interessante, não partiu deles nenhuma iniciativa de realizar negociações em separado por subsetores, como ocorreu no ramo metalúrgico.

No caso dos bancários, as conseqüências do processo de automação e reestruturação dos bancos, principalmente a enorme perda de postos de trabalho, tornaram muito mais difícil mobilizar a categoria, tanto no que diz respeito aos funcionários de um mesmo banco (o Banco do Brasil, por exemplo) ou setor (público ou privado), quanto no que se refere ao conjunto da categoria em nível nacional. Em conseqüência, as estratégias de mobilização do movimento sindical bancário foram mais restritas e não conseguiram superar a separação que se estabeleceu nas negociações realizadas para cada um dos bancos públicos (estaduais ou federais) e para o conjunto dos bancos privados representados pela Fenaban. Esta fragmentação das negociações foi prejudicial para o sindicalismo bancário, assim como para os metalúrgicos, atingindo principalmente os trabalhadores dos bancos públicos, atacados como "privilegiados" pelo discurso de corte neoliberal predominante ao longo desta década.

Entretanto, comparando a situação dos bancários com a das outras duas categorias estudadas, que vêm sendo cada vez mais pressionadas para a realização de negociações pontuais no âmbito de cada empresa, é possível perceber que aqueles conseguiram manter uma situação mais vantajosa, se bem que também no setor privado já se delineie uma tendência maior de negociação por banco.

No início da década, quando as condições de negociação já haviam piorado significativamente, os bancos privados passaram a ser o "carro-chefe" do movimento, a servir de parâmetro e a direcionar as negociações dos bancos públicos, invertendo a tendência predominante na década anterior. Mas, diferentemente dos anos 80, este papel não significou uma aceleração das possibilidades de ganhos que então poderiam ser estendidos aos demais bancos. Significou, ao contrário, apesar das inúmeras perdas, a manutenção de um certo padrão de garantias trabalhistas, que de outra forma poderia ter sido diminuído brutalmente nos bancos públicos. Entretanto, a partir de meados da década pode-se perceber que nem mesmo este padrão conseguiu ser mantido, pois verificou-se um agravamento ainda maior das condições de negociação nos bancos públicos, que paulatinamente também se estendeu para os bancos privados. Portanto, a negociação em separado realizada nos bancos produziu um nivelamento "por baixo".

No entanto, a comparação dos resultados das negociações nestas três categorias permite afirmar que, ainda que os bancários tenham sofrido perdas nesta década, sobretudo nos bancos públicos, o fato de apresentarem, pelo menos no setor privado, uma estrutura de negociação unificada nacionalmente contribuiu em grande medida para que esta categoria alcançasse melhores resultados do que as demais no contexto dos anos 90. Assim, se a fragmentação das negociações por subsetores teve impactos negativos para a categoria metalúrgica, e se, no caso dos químicos, as negociações unificadas no âmbito estadual e puxadas pelas empresas mais dinâmicas resultaram em perdas menores, pelo menos até 1995, no caso dos bancários, ainda que as negociações se tenham pautado pelo setor no qual o movimento sindical foi se tornando mais enfraquecido - o setor público —, os sindicatos conseguiram evitar perdas maiores nos bancos públicos e até uma ampliação de cláusulas sociais nos bancos privados devido, fundamentalmente, à negociação nacional conseguida, provavelmente também em razão da existência de menores divergências políticas entre os sindicatos deste ramo.

Podemos concluir que o retrocesso observado nas negociações destas três categorias na década de 90 mostra o debilitamento dos sindicatos, como decorrência dos impactos negativos do processo de reestruturação destes setores e principal- 
mente do crescimento assustador do desemprego. Mas isto não significa, necessariamente, o fracasso ou a total inadequação das práticas de negociação unificadas por categoria e da forma sindical de organização dos trabalhadores diante das novas condições do mundo do trabalho. Pois se, de um lado, há indícios de uma crise destas práticas, de outro, as experiências dos químicos e bancários nos anos 90, como as de muitas outras categorias no país, indicam que não há muita disposição de setores importantes do patronato - enquanto há, sim, grande resistência entre os sindicatos de trabalhadores - de romper com as negociações por categoria e substituí-las por negociações por empresa ou por local de trabalho.

A fragilização e perda de poder de barganha dos sindicatos, que é real, não parece apontar necessariamente para uma tendência de crise irreversível e desaparecimento desta forma de organização, pois a capacidade de resistência que verificamos nestas categorias ao longo da década, conforme a conjuntura foi se tornando gradativamente mais desfavorável aos trabalhadores, deveu-se, fundamentalmente, à presença de sindicatos combativos. Assim, ainda que não tenham ocorrido avanços nas negociações, com a ampliação de direitos e conquistas, foi o trabalho efetivo dos sindicatos contra a ofensiva patronal e do governo ${ }^{28}$ que conseguiu evitar perdas maiores e incorporar aos acordos, mesmo que de forma pontual, algumas novas garantias. Portanto, esta capacidade de resistência dos sindicatos, mesmo por meio de uma estratégia predominantemente defensiva, é um fator que os legitima como representantes dos trabalhadores "sobreviventes", que têm sido efetivamente protegidos diante das dificuldades e perversidades colocadas pela reestruturação financeira e produtiva. É verdade que, como resultado de estratégias defensivas, esta proteção está muitas vezes aquém das demandas e interesses destes trabalhadores, mas tem surtido melhores resultados do que os observados no caso de categorias cujos sindicatos inexistem ou são acomodados ou muito pouco organizados.

Cabe considerar, no entanto, que o crescimento exponencial do desemprego e do trabalho informal e terceirizado impõe um amadurecimento do movimento sindical, no sentido de repensar o seu formato corporativista e suas estratégias de recrutamento, de organização e de enfrentamento das questões postas pelas aceleradas mudanças econômicas, tecnológicas e gerenciais, que redefinem o papel, o lugar e as formas do trabalho nesta virada do milênio.

\section{NOTAS}

1 Entendemos por políticas neoliberais um conjunto de medidas econômicas inspiradas no liberalismo econômico contemporâneo, que rejeita a intervenção do Estado na economia e defende a superioridade do mercado, a concorrência e a liberdade de iniciativa como mecanismos capazes de assegurar a soberania do consumidor, o crescimento da riqueza e o desenvolvimento humano. Boito Jr. (1999) distingue no discurso neoliberal a ideologia teórica da ideologia prática. Esta última corresponde ao modo como os governos inspirados na doutrina neoliberal selecionam as áreas e atividades nas quais seus princípios devem ser aplicados; corresponde, portanto, às políticas neoliberais. No Brasil, as idéias neoliberais passaram a ter influência crescente nas políticas governamentais desde o começo da década de 90. As políticas neoliberais adotadas desde o governo Collor até o atual governo podem ser identificadas principalmente na redução da atividade econômica do Estado através das privatizações, na abertura comercial, na desregulamentação financeira e na desregulamentação do mercado de trabalho, juntamente com a redução de direitos sociais (Boito Jr., 1999; ver também Wainwright, 1994).

2 A macrorregião de Campinas é formada por 83 municípios e é a mais importante área econômica do Estado de São Paulo após a Região Metropolitana de São Paulo (Negri, 1990, p. 88). Em 1990, a população da região atingiu 4,5 milhões de habitantes (13\% da população do Estado de São Paulo). A região caracteriza-se pela existência de um setor industrial extremamente dinâmico, que cresceu mesmo durante os anos 80 , e por ser a segunda maior praça bancária do Brasil. Sua estrutura industrial reúne uma enorme variedade de setores e atividades e seus principais segmentos são, em ordem decrescente, química, metal-mecânica, têxtil e alimentos.

3 Pesquisas realizadas nos setores de autopeças, máquinas-ferramentas e computadores: Rabelo (1989); Gitahy e Rabelo (1988 e 1992); Gitahy, Rabelo e Costa (1992); Ruas, Gitahy, Rabelo e Antunes (1994); Rachid (1994); Rachid e Gitahy (1995); Gitahy, Cunha, Previtalli e Rachid (1997).

4 Neste texto, definimos terceirização como o ato de uma empresa transferir a provisão de serviços ou de atividades produtivas, antes desenvolvidas pela própria em- 
presa nas suas próprias instalações, para uma terceira parte, que assume a responsabilidade da execução destas atividades para a empresa contratante sob determinadas condições contratuais (Reilly e Tamkin, 1996; Young, 2000). Esta definição inclui a possibilidade de que a execução das atividades terceirizadas seja realizada no interior da empresa contratante, mas supõe que a terceira parte (seja ela uma empresa ou trabalhadores autônomos) esteja fora das relações e condições de emprego que governam os empregados da contratante. Assim definida, a noção de terceirização permite distinguir o fenômeno mais recente de externalização de atividades de formas tradicionais de subcontratação, como as que se encontram na provisão de materiais da indústria da construção civil e de partes da produção na indústria de confecção.

5 De acordo com entrevistas realizadas em 1988 com trabalhadores e diretores do Sindicato dos Químicos de Campinas ligados a este setor.

6 Assim, se em 1990 uma primeira medida de ajuste à perspectiva de término da inflação acarretou a demissão de quase 80 mil bancários em todo o país, de 1994 a 1996 o aprofundamento da reestruturação levou à demissão de mais 140 mil bancários.

7 Como pode ser observado na tabela abaixo, há um crescimento do setor farmacêutico no país e também em Campinas. Mas no setor de plástico verifica-se uma queda no emprego no plano nacional e um crescimento deste em Campinas.

\begin{tabular}{|c|c|c|c|c|c|c|}
\hline \multirow[b]{2}{*}{ Anos } & \multicolumn{2}{|c|}{$\begin{array}{c}\text { Indústria Química } \\
\text { e Petroquímica }\end{array}$} & \multicolumn{2}{|c|}{$\begin{array}{c}\text { Indústria } \\
\text { Farmacêutica }\end{array}$} & \multicolumn{2}{|c|}{$\begin{array}{l}\text { Indústria } \\
\text { de Plástico }\end{array}$} \\
\hline & Brasil & Campinas & Brasil & Campinas & Brasil & Campina \\
\hline 1986 & 247.554 & 9.516 & 53.500 & 1.841 & 193.120 & 3.362 \\
\hline 1996 & 200.801 & 8.330 & 71.760 & 4.023 & 187.917 & 5.246 \\
\hline
\end{tabular}

Fonte: RAIS/Ministério do Trabalho.

8 Liliana Segnini questiona a qualificação das gerências, que, segundo ela, passaram a trabalhar com informações e dados normatizados em softwares, não dispondo de autonomia para decidirem e lidarem com situações que ultrapassem as opções preestabelecidas nestes programas. Cf. palestra proferida no IFCH/Unicamp em 9/ 6/1999. Ver também Segnini (1996).

9 As indústrias químicas deslocaram-se para a região de Campinas nos últimos anos em busca de novas oportunidades de negócios, custos mais baixos, e também devido à forte tradição de luta do movimento sindical na capital e no ABC paulista.

10 Informações obtidas no Sindicato dos Químicos de Campinas, a partir do Boletim Sindical de janeiro de 1983, da ata de apuração das eleições de maio de 1996 e do Cadastro Financeiro do Sindicato de julho de 1998.

11 De acordo com dados obtidos no boletim sindical $O$ Bancário.

12 A paralisação dos centros de processamento de dados e dos centros de compensação era um forte instrumento de pressão dos bancários em prol de suas demandas nas campanhas salariais dos anos 80, pois comprometia o funcionamento de todo o sistema financeiro nacional, que já era interligado.

13 O sindicato representa, atualmente, cerca de 1.500 empresas e 40 mil operários, sendo 14 mil deles sindicalizados.

14 A mudança no padrão da negociação coletiva foi também afetada pela redução do número de greves. Estudo recente (Noronha, Gebrim e Elias Jr., 1998) mostra que a partir de 1992 houve uma diminuição sensível no número, extensão e impacto político dos movimentos grevistas. Entre os metalúrgicos não ocorreram greves de toda a categoria na década de 90, mas apenas greves restritas a grupos de empresas.

15 Análise elaborada a partir do exame das convenções coletivas estabelecidas entre os sindicatos dos metalúrgicos e os sindicatos patronais do setor no Estado de São Paulo de 1990 a 1998.

16 Por exemplo, em julho de 1992, enquanto as montadoras acordaram $11,3 \%$ de reajuste em julho mais a inflação do mês e antecipações mensais, o Grupo 5 e o Grupo da Fundição deram 6\% em julho, 4\% em setembro e $4 \%$ em outubro, mais a variação do INPC. Os Grupos 8 e 10 concederam 6,8\%, mais o INPC em julho, agosto e outubro.

17 As cláusulas que os sindicalistas e empresários chamam de "sociais" correspondem, na verdade, àquelas referentes às condições de trabalho (transporte, alimentação, auxílios, licenças, estabilidades especiais etc.), às condições ambientais, de saúde e segurança no trabalho (atendimento médico, convênio médico, prevenção de acidentes etc.), às relações de trabalho (admissão, estrutura de cargos e promoções, rescisão de contrato) e aos direitos sindicais (acesso dos dirigentes às empresas, quadro de aviso, sindicalização, informações das empresas, contribuição assistencial etc.).

18 Entrevista com Eliezer Mariano da Cunha, diretor do Sindicato dos Metalúrgicos de Campinas, concedida a Carolina R. M. Justo e Angela M.C. Araújo em maio de 1998.

19 Entrevistas com Jorge Rodrigues e Sávio Domingues, diretores do Sindicato dos Químicos de Campinas e Região, concedidas a Daniela M. Cartoni e Angela M.C. Araújo, respectivamente, em novembro e dezembro de 1997.

20 Como aconteceu entre os metalúrgicos, com exceção dos primeiros anos da década, quando ocorreram movimentos grevistas mais amplos, não houve, nos anos 90, nenhuma greve que tenha atingido o conjunto da categoria no estado; os poucos movimentos grevistas registrados atingiram apenas grupos de empresas.

21 Um acordo importante foi assinado neste ano com a Rhodia, tendo como pontos principais: duração média da jornada de trabalho de 36 horas semanais para os trabalhadores de turnos ininterruptos; permanência do quinto turno; cláusulas sobre o controle do trabalho e intervalo para refeições e descanso; valor da hora extra; cursos de formação e de aperfeiçoamento profissional. 
22 Em 1991, dos 301,17\% reivindicados, a Fenaban concedeu um reajuste de $99,05 \%$. No Banco do Brasil e na $\mathrm{CEF}$, onde a reivindicação era maior, de 510,14\%, em função das perdas acumuladas desde o ano anterior, o reajuste foi de apenas 100\%. Em 1995, quando a política salarial (ainda existente) previa um reajuste de $21 \%$, a Fenaban concedeu 30\% (dos 48,67\% reivindicados), ao passo que na CEF e no Banco do Brasil foi seguida a política salarial, por decisão do Tribunal Superior do Trabalho (TST).

23 Em 1996, a Fenaban e o Banespa concederam um reajuste de 10,8\%, dos 21,08\% reivindicados, e em 1997 mais $5 \%$, dos $22,68 \%$ reivindicados.

24 Entrevista com A.L.S. realizada em 15/5/1998.

25 Com exceção da CEF e do Banco do Brasil, cujos acordos de 1997 proibiram as demissões durante sua vigência. Mas isto ocorreu depois de uma imensa redução no quadro funcional empreendida por estes bancos.

26 Já o Banco do Brasil concordou com o pagamento da gratificação de caixa por um ano aos bancários que retornassem ao trabalho após afastamento por LER e com a realização de rodízio entre as funções que exigem esforços repetitivos.

27 Convém mencionar, no entanto, as negociações em torno da reestruturação realizadas com a Nossa Caixa, que minimizaram perdas para os funcionários. Em 1990 foram interrompidas demissões no CPD do banco; em 1995, a Nossa Caixa concordou com a prorrogação da transferência do setor de compensação para São Paulo e aceitou discutir com os sindicatos a introdução de novas formas de gestão. Em 1997, as negociações permitiram a manutenção da quantidade de agências e de funcionários do banco e aprovaram a contraproposta dos sindicatos de substituição da licença-prêmio por uma gratificação variável.

28 Os governos de Fernando Collor de Mello e Fernando Henrique Cardoso tentaram introduzir legislação desregulamentadora do mercado de trabalho e que visava também mudar a estrutura sindical e a prática da negociação coletiva centralizada, obtendo um certo sucesso, até o momento, quanto à flexibilização dos contratos e da jornada de trabalho e à introdução de formas de salário variável.

\section{BIBLIOGRAFIA}

ABRAMO, Laís. (1998), "Um olhar de gênero. Visibilizando precarizações ao longo das cadeias produtivas", in Laís Abramo e Alice R.P. Abreu (orgs.), Gênero e trabalho na Sociologia latinoamericana, São Paulo/Rio de Janeiro, ALAST (Série II, Congresso Latino-Americano de Sociologia do Trabalho).
ARAÚJO, Angela M.C. e GITAHY, Leda. (1998), Reestruturação produtiva e negociações coletivas entre os metalúrgicos paulistas. Trabalho apresentado no XXI Congresso Internacional da Latin American Studies Association, Chicago.

BAGLIONI, Guido. (1994), "As relações industriais na Europa nos anos 80", in Carlos A. Oliveira et al. (orgs.), O mundo do trabalbo, São Paulo, Cesit/Scritta.

BLASS, Leila M.S. (1993), “Automação bancária: práticas e representações”. São Paulo em Perspectiva, outubro-dezembro.

BOITO JR., Armando. (1999), Política neoliberal e sindicalismo no Brasil. São Paulo, Xamã.

BRAGA, José Carlos de Souza. (1993), "A financeirização da riqueza”. Economia e Sociedade, Revista do Instituto de Economia da Unicamp, 2, agosto.

BRESCIANI, Luís Paulo. (1994), "Reestruturação industrial e negociação coletiva: o sindicalismo brasileiro vai à luta?", in Heloísa de S. Martins e J. Ricardo Ramalho (orgs.), Terceirização: diversidade e negociação no mundo do trabaIho, São Paulo, Hucitec.

CARVALHO, R. e SCHMITZ, H. (1990), "O fordismo no Brasil”. Novos Estudos Cebrap, São Paulo, 237, julho.

CASTRO, Nadya. (1998), Qualificação, mercados e processos de trabalho: estudo comparativo do complexo químico brasileiro. Relatório final do Projeto II, Reestruturação Produtiva e Qualificação, Programa de Pesquisa em Ciência e Tecnologia, Qualificação e Produção, São Paulo, Cedes/Finep/PDCT-CNPq.

CASTRO, Nadya e GUIMARÃES, Antônio Sérgio A. (1991), "Competitividade, tecnologia e gestão de trabalho: a petroquímica brasileira nos anos 90", in M. Leite e R.A. da Silva (orgs.), Modernização tecnológica, relações de trabalho e práticas de resistência, São Paulo, Iglu, pp. 43-65.

DRUCK, Maria da Graça. (1997), "Flexibilização, terceirização e precarização: a experiência dos sindicatos", in Tânia Franco (org.), Trabalbo, riscos industriais e meio ambiente: rumo ao desenvolvimento sustentável?, Salvador, Edufba.

(1999), Terceirização: (des)fordizando a fábrica - um estudo do complexo petroquímico da Babia. São Paulo, Boitempo Editorial/ Edufba. 
FEBRABAN. (1994), Projeto qualidade em atendimento. São Paulo, Febraban, mimeo.

FREITAS, Maria C. Penido de. (1998), "A abertura do sistema bancário brasileiro ao capital estrangeiro", in Fundação do Desenvolvimento Administrativo (Fundap), Abertura externa e sistema financeiro (relatório final), São Paulo, maio.

GITAHY, Leda e BRESCIANI, Luís Paulo. (1997), Reestruturação produtiva e trabalho na indústria automobilística brasileira. Campinas, DPCT/IG/Unicamp, mimeo, julho.

GITAHY, Leda, CUNHA, Adriana M., PREVITALLI, Fabiane S. e RACHID, Alessandra. (1997), Relações interfirmas e gestão de recursos humanos na cadeia produtiva de autopeças. Relatório de pesquisa, projeto Reestruturação Produtiva, Trabalho e Educação, Campinas, Finep/ Cedes/CNPq.

GITAHY, Leda e RABELO, Flávio. (1988), "Os efeitos sociais da microeletrônica na indústria metalmecânica brasileira: o caso da indústria de informática". Anais do Seminário Padrões Tecnológicos e Politicas de Gestão: Processos de Trabalbo na Indústria Brasileira, Campinas/ São Paulo, DPCT/IG/Unicamp, Depto de Sociologia/FFLC/USP e FEA/USP.

(1992), "Educacion y desarrollo tecnológico: el caso de la industria de autopartes", in M.A. Gallart (org.), Educacion y trabajo desafios y perspectivas de investigacion y politicas para la decada de los noventa, Montevidéu, Red Latinoamericana de Educación y Trabajo CIID-CENEP/Cinterfor, pp. 107-141.

GITAHY, Leda, RABELO, Flávio e COSTA, Maria Conceição. (1988), Inovação tecnológica e políticas de gestão: difusão de novas tecnologias e subcontratação em empresas metalmecânicas de São Paulo. Trabalho apresentado no XII Encontro Anual da Anpocs, Águas de São Pedro, SP, outubro.

(1992), "Innovación tecnológica: relaciones industriales y subcontratacción". Boletin Cinterfor, Montevidéu, Cinterfor/OIT, 120, julio-setiembre: 71-98.

HUMPHREY, J. (1993), "Adaptando o 'modelo japonês' ao Brasil”, in Helena Hirata (org.), Sobre o modelo japonês: automatização, novas formas de organização e de relações de trabalbo, São Paulo, Edusp.
JORNAL O BANCÁRIO. Sindicato dos Bancários de Campinas e Região, edições de 281 a 690, janeiro de 1990 a dezembro de 1997.

LARANGEIRA, Sônia M.G. (1997), "Reestruturação produtiva no setor bancário: a realidade dos anos 90”. Educação e Sociedade, ano XVIII.

LEITE, Márcia de P. (1994), "Reestruturação produtiva, novas tecnologias e novas formas de gestão da mão-de-obra", in Carlos A. Oliveira et al. (orgs.), O mundo do trabalho, São Paulo, Cesit/Scritta.

LEITE, Márcia e RISEK, Cibele. (1998), "Cadeias, complexos e qualificações”, in Márcia Leite e Magda A. Neves (orgs.), Trabalho, qualificação e formação profissional, São Paulo/Rio de Janeiro, ALAST (Série II, Congresso LatinoAmericano de Sociologia do Trabalho).

NEGRI, B. (1990), Diagnóstico setorial: a indústria de transformação no Estado de São Paulo 19701990. Relatório de pesquisa. Campinas, Instituto de Economia da Unicamp, mimeo.

NORONHA, Eduardo G., GEBRIM, Vera e ELIAS JR., Jorge. (1998), Explicações para um ciclo excepcional de greves: o caso brasileiro. Trabalho apresentado no XXI Congresso Internacional da LASA, Chicago, 24-26 de setembro.

POSSAN, Magali A. (1997), "A malha entrecruzada das ações”. Coleção Campiniana, Centro de Memória da Unicamp e Sindicato dos Metalúrgicos de Campinas e Região, 14.

POSTHUMA, Anne C. (1995), “Técnicas japonesas de organização nas empresas de autopeças no Brasil", in Nadya A. Castro (org.), A máquina e o equilibrista: inovações na indústria automobilística brasileira, São Paulo, Paz e Terra.

RABELO, Flávio. (1989), Automação, estrutura industrial e gestão da mão-de-obra: o caso da introdução de máquinas-ferramentas com comando numérico na indústria metal-mecânica. Tese de mestrado. Campinas, Instituto de Economia da Unicamp.

RACHID, Alessandra. (1994), O Brasil imita oJapão? A qualidade em empresas de autopeças. Dissertação de mestrado. Campinas, DPCT/IG/Unicamp.

RACHID, Alessandra e GITAHY, Leda. (1995), "Programas de qualidade, trabalho e educação". Em Aberto, Brasília, INEP/MEC, ano XV, 65, jan.-mar.: 63-93. 
REILlY, P. e TAMKIN, P. (1996), "Outsoursing: a flexible option for the future?". IES Report, The Institute for Employment Studies, Brighton, UK, 320.

REVISTA CONJUNTURA ECONÔMICA. (1993-1998), vols. 47 a 52 .

REVISTA PROSA \& VERBO. (1997), CNB/CUT.

RIZEK, Cibele S. (1994), O trabalbo e suas metáforas - as representações simbólicas dos trabalbadores petroquímicos paulistas. Tese de doutoramento. São Paulo, Universidade de São Paulo.

RUAS, Roberto L., GITAHY, Leda, RABELO, Flávio e ANTUNES, Elaine. (1994), "Inter-firm relations, collective efficiency and employment in two Brazilian clusters". International Labour Office Working Paper, 242, March.

SALERNO, Mário S. (1993), "Modelo japonês, trabalho brasileiro", in Helena Hirata (org.), Sobre o modelo japonês: automatização, novas formas de organização e de relações de trabalho, São Paulo, Edusp.

SEGNINI, Liliana R.P. (1996), Mulher em tempo novo - mudanças tecnológicas nas relações de trabalho. Tese de livre-docência. Campinas, Faculdade de Educação da Unicamp.

SILVA, Leonardo M. (1997), A generalização dificil: a vida breve da Câmara Setorial do Complexo Químico, seguida do estudo de seus impactos em duas grandes empresas do ramo em São Paulo. Tese de doutoramento. São Paulo, FFL$\mathrm{CH} / \mathrm{USP}$.

SILVA, Roque A. (1992), "La negociación colectiva en el Brasil y el sistema de relaciones de trabajo", in Laís Abramo e Alberto Cuevas (orgs.), El sindicalismo latinoamericano en los 90. Volumen II: Negociación colectiva y sindicatos, Santiago, CLACSO.

WAINWRIGHT, Hilary. (1994), Arguments for a new left: answering the free market right. Londres, Blackwell.

YOUNG, Suzanne. (2000), "Outsoursing: lessons from the literature". Labour E Industry, 10, 3, April. 